\title{
Assessing groundwater status and human perception in drought-prone areas: a case of Bankura-I and Bankura-II blocks, West Bengal (India)
}

\author{
Mantu Das $^{1}$ (D) Tania Parveen $^{1}$ (D) . Deep Ghosh ${ }^{1}$ (D) . Jiarul Alam ${ }^{1}$ (D)
}

Received: 26 June 2021 / Accepted: 17 August 2021 / Published online: 14 September 2021

(c) The Author(s), under exclusive licence to Springer-Verlag GmbH Germany, part of Springer Nature 2021

\begin{abstract}
Ground water is a precious natural resource in every aspect of human life from natural to artificial environment. Ground water is an indicator of regional development by improving the economic domain through intensive agricultural practices, and aesthetic value through sufficient ground water supply as drinking water, fertile soil, and healthy vegetation. However, ground water availability and associated human perceptions were the main themes of the present study. In this study, both primary and secondary data were incorporated to understand the human adaptation behaviour in drought-prone areas of the fringe of Chhotanagpur plateau region (Bankura-I and II blocks) to ground water storage. GWPZ mapping is a very important exposure to knowing the ground reality. So, the MCDM-AHP method has been developed based on the eight dominant conditioning factors viz. geomorphology, lithology, lineament density, soil, drainage density, LULC, average slope, and slope aspect using GIS analytics with field expertise. The output result was validated with comparing 105 inventory stations where 0.850 AUC value was good for accepting the GWPZ model. As a result, a major portion of the study area is dominated by poor to moderate possibilities of ground water level (ground water level drops 1-2 m during the pre-monsoon) due to Proterozoic granite gneiss formation over the study area. With comparing demographic status, it was not favourable for a healthy lifestyle. Agriculture dominated rural environment of Bankura-I and II blocks is far away from the modern digital environment that is why ground water has played a very crucial role in the field of development. Moreover, to build up a good level of ground water recharge zone through rainfall harvesting, and sustainable land use planning will be the best management practices. So, availability of ground water should be a positive sign of development in the field of the economic sector and sustainable human society.
\end{abstract}

Keywords Groundwater resource $($ GWR $) \cdot$ Groundwater potentiality $($ GWP $) \cdot$ Drought $\cdot$ Human perception · Analytical hierarchy process (AHP)

Tania Parveen

msttaniaparveen@gmail.com

Mantu Das

rs_mantudas@nbu.ac.in

Deep Ghosh

rs_deep@nbu.ac.in

Jiarul Alam

geojia94@gmail.com

1 Department of Geography and Applied Geography, University of North Bengal, Darjeeling 734013, India

\section{Introduction}

Groundwater is one of the world's most valuable natural resources, providing a crucial and dependable source of water in all the climate zones of the world. Groundwater is in high demand in locations where surface water supplies are limited or non-existent (Nag and Ghosh 2013). It is a reliable source of water for domestic, agricultural, and industrial applications (Nag and Das 2017). The rate of groundwater use is rapidly increasing throughout the world with population growth (Al Adaileh et al. 2019; Gogu and Dassargues 2000). As a result, the dependency on groundwater is fast increasing. These expanding needs frequently lead to overexploitation, putting a significant strain on the limited supply of freshwater (Ahmed et al. 2021). Hence, groundwater 
depletion because of rising water demand for agricultural, household, and industrial purposes is a major concern all over the world (Gleeson et al. 2012; Scanlon et al. 2007). In many places of the world, including north Africa, the Middle East, south and central Asia, north China, North America, and Australia groundwater resources are being depleted (Konikow and Kendy 2005; Doll et al. 2014; Dalin et al. 2017; Ouyang et al. 2021). One-third of the world's population lives in places where there is a water shortage, with 1.1 billion people currently living without access to safe drinking water (Shaw and Thaitakoo 2010). Furthermore, due to unplanned irrigation patterns, high population density, and climatic change, groundwater problems have intensified, mostly in tropical and subtropical countries (Ahmed et al. 2021). Around 1.5 billion people rely on groundwater, while 2.53 billion people live in areas where water is scarce (Shen et al. 2015). In addition, the rate of water usage doubles every 20 years, approximately the doubling growth of population expansion in the world, and it is anticipated that by 2025 a minimum 3 billion people would be living in locations where it will be very difficult to solve the scarcity of basic water demands (Abedin et al. 2014). Groundwater (specifically from dug wells and tube wells) is the principal water supply for agriculture, industry, and home uses, etc., especially in dry zones where annual rainfall is low (Roy et al. 2020) whereas Taylor et al. (2013) have mentioned in their studies that about $42 \%$ of pumped groundwater is used for agriculture purpose. In general, the accessibility of groundwater and its quality are regulated by a range of factors, including geology, the intensity of chemical weathering of the prevailing lithology, the quantity of recharge water, pollution status and contributions from non-water-rock interaction sources (Hussein 2004).

Bankura is located within the red lateritic zone in West Bengal (Nag and Kundu 2016). The area is very susceptible to any change in rainfall due to the limited water holding capacity of soil, excessive drainage, surface runoff, and significant soil erosion (Milly 1994). This area also has a highly variable annual rainfall and is subject to recurrent droughts (Mukherjee and Patil 2013; Das et al. 2017; Roy et al. 2020). Moreover, water shortages have become a serious worry in India, particularly in the arid and semi-arid regions, due to the vagaries of the monsoon and a scarcity of surface water (Bhunia et al. 2018). Furthermore, in India, more than $90 \%$ of the rural population and roughly $30 \%$ of the urban population depend on groundwater for drinking and household requirements (Roy et al. 2020).

In recent years, groundwater resources in India and other countries have been depleting at an alarming rate, and they are not being recovered rapidly enough.

In dry, drought-prone areas of the world, groundwater is the only source of long-term water supply, and it is currently being progressively used for public drinking water and agricultural reasons (Peters et al. 2005; Senapati and Das 2021). Bankura is in a semi-arid region which often experiences periods of below-average rainfall. Most of the surface water sources, such as ponds and streams, completely dry up during pre-monsoon and post-monsoon season due to the low rainfall and shortage of supply of water supplies during these times of the year (Nag 1998). As communities in Bankura have experienced severe water shortages over recent years, the population have had to change their water use practices due the changes in water availability. The perception of people in the region of groundwater accessibility depends on the nature of water availability, the extent of government interference and monsoonal activity (Hazra et al. 2017). Consequently, the people of this area have adapted to balance their livelihood with the availability of groundwater (Chatterjee 2018). Considering these factors, it is therefore important that the most suitable locations for obtaining groundwater in the region are identified in a manner that can be readily communicated to local communities.

Consequently, this study has been undertaken to determine the likely availability of groundwater in the area and to determine the community perception of groundwater availability. Information from this study could be used to improve planning and management measures in the region to improve the sustainability of groundwater use.

\section{Brief description of the study area}

Bankura is one of the important westernmost districts of West Bengal, and its location on the Tropic of Capricorn makes this district climatologically significant. It is indeed a semi-arid area but it is extremely vulnerable to drought. The study area is located on the groundwater management blocks which are the Bankura Block I and Block II which feature an undulating terrain and are underlain by Precambrian crystalline rocks (Fig. 1). The Bankura I and Bankura II in blocks are located between $23^{\circ} 09^{\prime} 24^{\prime \prime}-23^{\circ} 22^{\prime} 51^{\prime \prime}$ North latitude and $86^{\circ} 53^{\prime}$ $51^{\prime \prime}-87^{\circ} 14^{\prime} 19^{\prime \prime}$ East longitude. Geographically, the area of Bankura district comprising Bankura I and Bankura II forms the far eastern sight of the Ranchi Plateau, which associated with the depositional fluvial terraces of the Dwarakeswar-Gandheswari Rivers as it moves east (Nag and Das 2017). According to the Census (2011), the total population of Bankura District is 35, 96,674 in which Bankura I and Bankura II CD block had a total population of 107,685 and 140,864 , respectively. The density of population in Bankura I is 574 per square kilometre and Bankura II is 640 per square kilometre. Based on the research facts, Dhaldanga is the most densely populated village in Bankura I CD block, followed by Andharthaul, Kalapathar, Kenjakura, Achuri, and Jagadalla (Fig. 2). The 


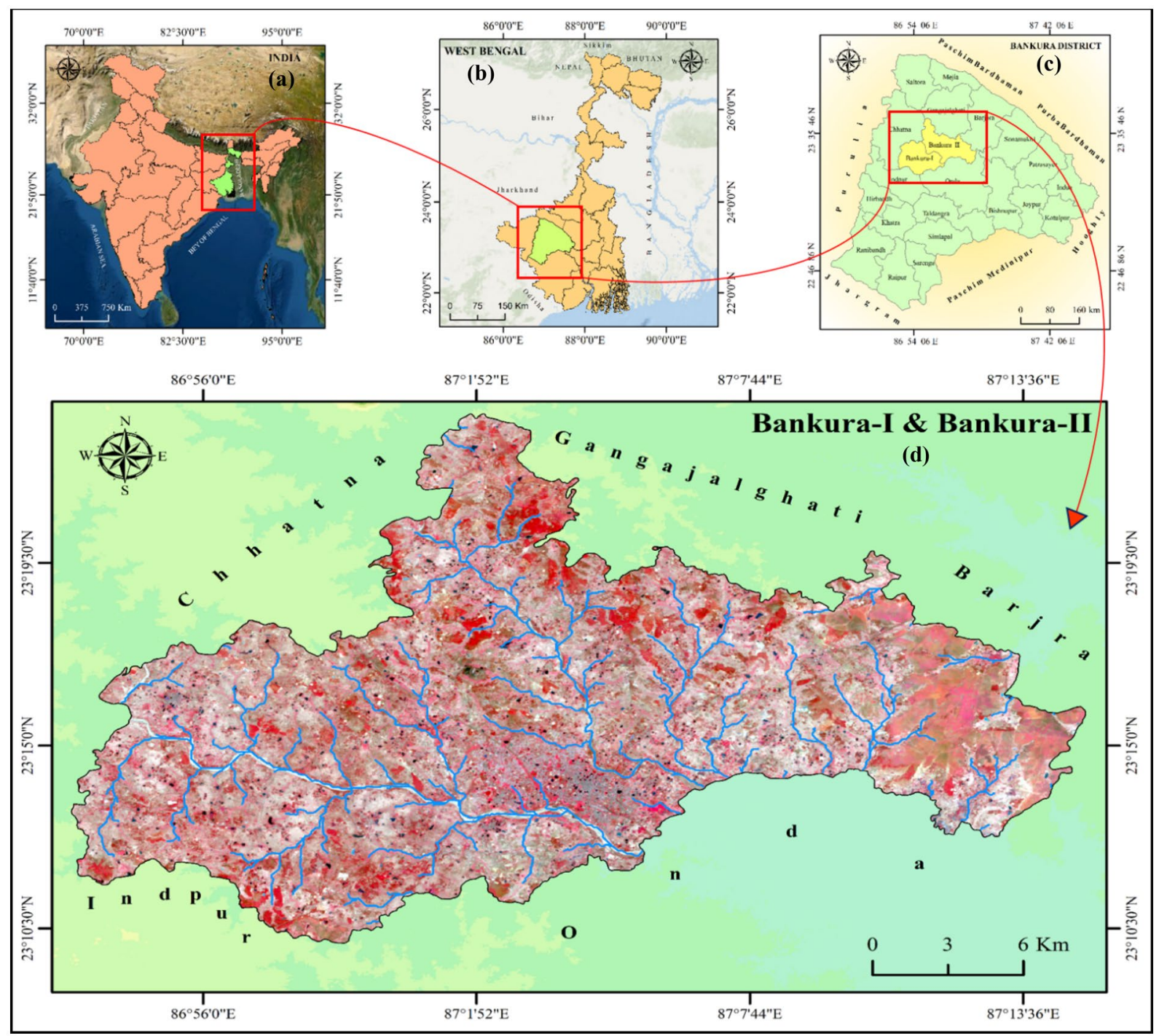

Fig. 1 Location and geographical settings of the study area along with important drainage networks (a) the location of West Bengal state in India (b) the location of Bankura district in West Bengal (c)

maximum household density in Bankura-I and II is 1416 per square kilometre, with a minimum density of 1 per square kilometre. Gauripur, Achuri, Papurdihi, Balardihi, and Sanaband are among the villages in Block BankuraI that have a greater household density. Susunia, Helna, Nutangaon, Bhikurdihi, Baindhka, and Dakshin Bankati are among the villages in Block Bankura-II that have a greater household density (Fig. 3). The difference between the demand and supply of water is widening every day as the world's population increases. Both the physical and economic water shortages threaten to the people of this areas. The research region has been taken into consideration because of this and to better understand the current the location of Bankura I and II blocks in Bankura district (d). Study area showing FCC format of Landsat 8 imagery along with surface elevation map

situation, as well as the local people's ability to adjust to it and their opinion of the crisis (see Fig. 3).

\section{Data and methodology}

\section{Data sources and preparation of the thematic layers for GWPM}

To identify the groundwater potential zones (GWPZ) of the Bankura I and II blocks in the drought-prone region of West Bengal, eight thematic layers were selected viz. geomorphology, lineament density, lithology, average slope, slope 
Fig. 2 Population density (person $/ \mathrm{km}^{2}$ ) in Bankura I and Bankura II. Population data have been collected form district statistical handbook, Bankura district (2011)

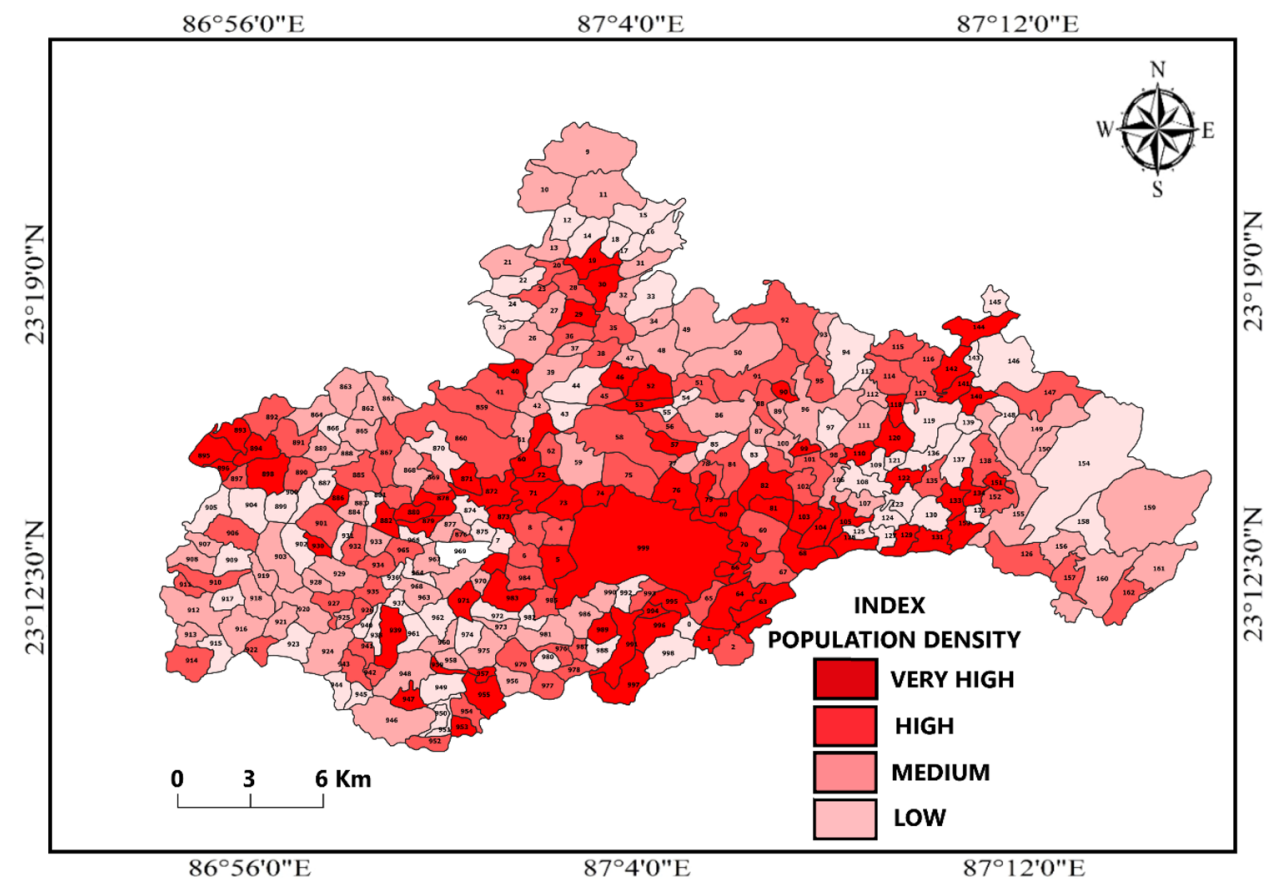

Fig. 3 Household density (household $/ \mathrm{km}^{2}$ ) in Bankura I and Bankura II. Data have been collected form district statistical handbook, Bankura district (2011)

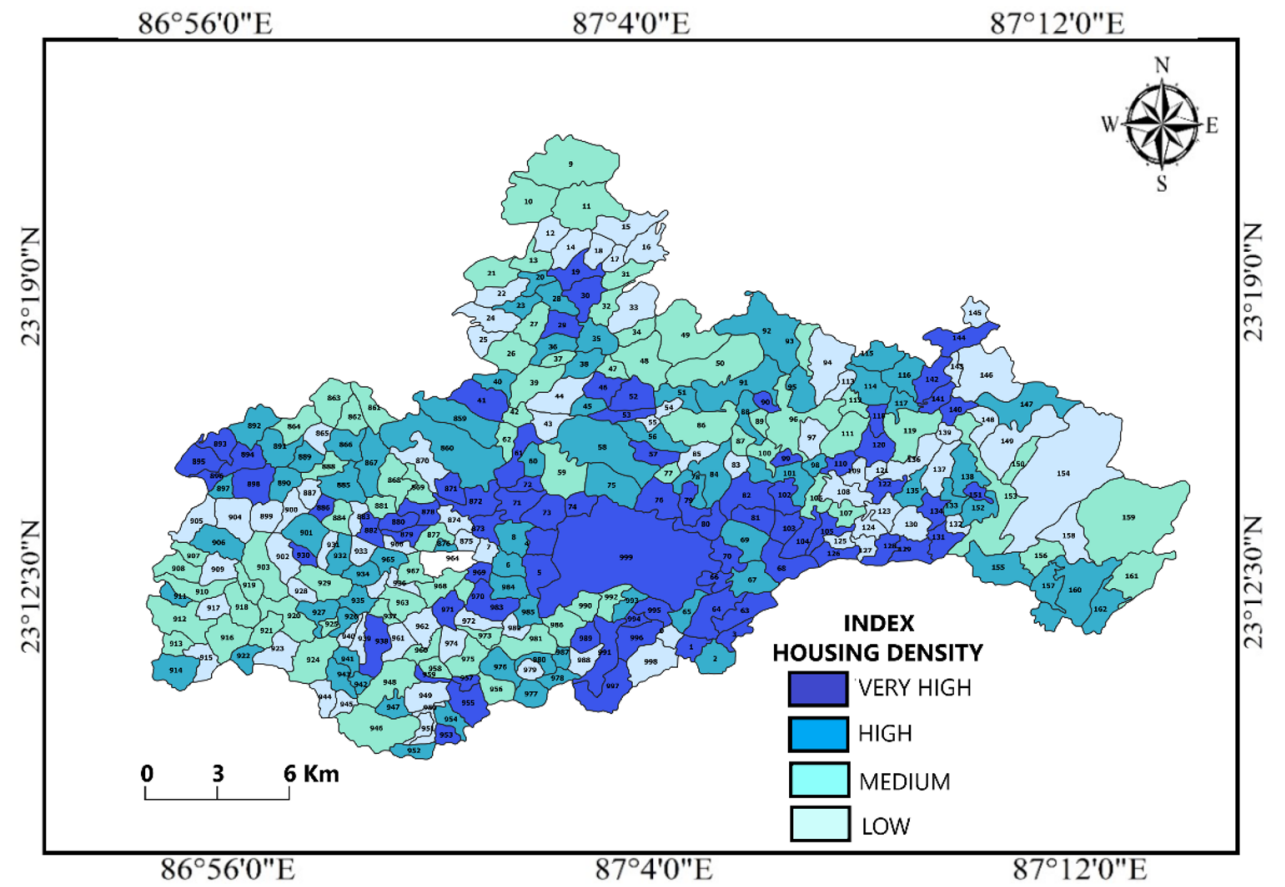

aspect, soil type, LULC, and drainage density. All these layers have been processed and executed using the GIS analytics (ArcMap 10.5), based on both information from the literature, and field knowledge and investigations for assessing the final groundwater potential map (GWPM) output. All the selected thematic layers were transformed into a rasterized format, which was further projected into UTM Projection, WGS 84 Datum Zone 45, with a spatial resolution of $30 \mathrm{~m}$.
SRTM-DEM with $30 \mathrm{~m}$ spatial resolution was obtained from USGS Earth Explorer application to prepare the average slope, slope aspect, and drainage network information for the study area, which was also taken as a base map to prepare the drainage density map. At first, the DEM was preprocessed in the GIS environment (ArcMap 10.5) using the sink-filling, flow accumulation, and flow direction technique, and then a stream order tool was used. Finally, a $1 \mathrm{~km}^{2}$ grid 
was developed to prepare the drainage density and lineament density maps. For the preparation of LULC, Landsat 8 OLI (30 m spatial resolution) images were collected from USGS Earth Explorer website. At first, Landsat image (Row 44 and Path 139) was mosaic, which was later pre-processed using atmospheric correction, DNs value of the individual band was converted to the ToA radiance by the spectral radiance scaling method and ultimately converted to the ToA reflectance, edge enhancement, and band composition techniques. Finally, supervised classification with a maximum likelihood algorithm was performed to generate the final LULC map with five classes (i.e., water body, barren land, vegetation cover, agricultural land, and settlements). For geomorphology, lithology, and lineaments, the data were collected from the Geological Survey of India (GSI) website. The layer is available in vector format, which was initially pre-processed in the GIS environment and then converted into a raster layer (with a $30 \mathrm{~m}$ spatial resolution). The study area's soil map was collected from the National Bureau of Soil Survey (NBSS) and Land Use Planning (LUP) and extracted using the GIS platform. According to several studies, the kriging interpolation technique seems to be more accurate and reliable for the delineation of drainage density and lineament density maps than any other technique (Kim et al. 2011; Ly et al., 2013). Further, all data sources and their details are summarized in Table 1.

After preparing all the selected thematic layers into a rasterized format with the same cell size $(30 \mathrm{~m})$, reclassification was done. Then, weights were assigned using the Saaty's scale in AHP-Excel by K. D. Geopel version 15.08.2018 and further weighted overlay analysis (WOA) was performed by integrating all the raster layers in the GIS environment using a weighted overlay tool to delineate the final GWPM for Bankura-I and II blocks in the drought-prone Bankura district.

\section{Use of the analytical hierarchy process (AHP) for developing the groundwater potential zoning map}

AHP is a multi-criterion-based decision-making technique introduced by Saaty which is one of the most appropriate models for preparing the GWPZ map (Saaty 1980). The method was applied to a set of parameters to establish a hierarchical structure by giving weights to each criterion to reduce decision-making complexity (Kiker et al. 2005; Pramanik 2016). AHP is a systematic and powerful technique that integrates practical knowledge with subjective ideas to determine decision-making by assessing multiple variables based on expert views/experiences using the GIS platform (Sener et al. 2011; Hammami et al. 2019). To prepare accurate results, the assignment of weights to each parameter and their normalization is an utmost factor, as the outcome is exclusively conferred on the appropriate weight assignments (Muralitharan and Palanivel 2015). There are various weight estimation techniques, but AHP is one the most promising techniques in groundwater potential modelling that can produce the most reliable and cost-effective performance (Murmu et al. 2019).

The AHP model has been developed through four stages of functions. These steps are: the assignment of weights; development of a pairwise comparison matrix; carrying out a weight normalization; and undertaking a consistency ratio (CR) check (Hammami et al. 2019; Benjmel et al. 2020; Ghosh et al. 2021).

Table 1 Details of various data sets used for preparing the GWPM

\begin{tabular}{|c|c|c|c|c|c|}
\hline Data type & Detail of data & Available format & Extracted layer & Generated layer & GIS data type \\
\hline $\begin{array}{l}\text { Satellite } \\
\text { imagery }^{\text {a }}\end{array}$ & $\begin{array}{l}\text { Landsat } 8 \\
\text { Path-139 } \\
\text { Raw-044 } \\
\text { Acquisition date-28.02.2021 }\end{array}$ & Erdas imagine & LULC & LULC & Raster \\
\hline Geomorpho-logy map ${ }^{b}$ & Bhukosh-GSI & ESRI shapefile & Geomorpho-logy & Geomorpho-logy & Raster \\
\hline Lithology map ${ }^{b}$ & Bhukosh-GSI & ESRI shapefile & Lithology & Lithology & Raster \\
\hline Lineament map ${ }^{b}$ & Bhukosh-GSI & ESRI shapefile & Lineament & Lineament Density & Raster \\
\hline Soil map ${ }^{c}$ & $\begin{array}{l}\text { NBSS and LUP } \\
\text { WB Soil-Sheet } 1 \text { and } 2 \\
\text { Scale: } 1: 500,000\end{array}$ & JPG & Soil types & Soil types & Raster \\
\hline SRTM-DEM $^{\mathrm{a}}$ & $\begin{array}{l}\text { Entity ID: SRTM1N23E087V3 } \\
\text { Spatial resolution-30 m } \\
\text { Publication Date: } 2014-09-23\end{array}$ & TIFF & $\begin{array}{l}\text { Contour } \\
\text { Elevation } \\
\text { Drainage network }\end{array}$ & $\begin{array}{l}\text { Average slope } \\
\text { Aspect } \\
\text { Drainage Density }\end{array}$ & Raster \\
\hline
\end{tabular}

Source: ${ }^{a}$ USGS earth explorer (https://earthexplorer.usgs.gov/)

${ }^{\mathrm{b}}$ Bhukosh—geological survey of India (https://bhukosh.gsi.gov.in/)

${ }^{\mathrm{c}}$ National Bureau of Soil Survey and Land Use Planning (https://esdac.jrc.ec.europa.eu/) 
For the present study, a total of eight parameters were selected that are considered to regulate the occurrence of groundwater in the Bankura district. Here, expert opinions, field expertise, and multiple literature reviews were used to assign weights to each parameter (Magesh et al. 2012; Hammami et al. 2019). A high weight parameter resembles a high impact, and a low weight indicates a minor influence over the groundwater potential in the area.

At first, researchers selected factors that were considered to have a high importance in influencing groundwater occurrence, and described the criteria based on their significance, and influencing power towards groundwater potential (Tables 2 and 3). Then the assigned weights of each criterion were allotted based on Saaty's scale (ranges from 1 to 9 ) of relative importance to compare all parameters of the thematic layer in a matrix format with each other that is necessary in deriving the measurement. In Saaty's scale, 9 indicates extreme importance and 1 implies equal importance concerning the dominant factor (Table 4).

Table 5 shows the pairwise comparison matrix of groundwater formation factors, where parameters are arranged in a hierarchical order and assigned values according to their relative importance (Table 6). Scores of pairwise comparisons were normalized to prepare the standardized comparison matrix for flood susceptibility mapping. Consistency of the AHP method was then measured by the following equations (Das 2020):

$\mathrm{CR}=\frac{\mathrm{CI}}{\mathrm{RI}}$,

where,

$\mathrm{CI}=\frac{\lambda \max -n}{n-1}$
Table 2 Assigned and normalized ranks of different features of eight conditioning factor for groundwater potential mapping

\begin{tabular}{|c|c|c|c|c|c|}
\hline \multirow[b]{2}{*}{$\mathrm{i}$} & \multirow[b]{2}{*}{$\mathrm{j}$} & \multirow{2}{*}{$\begin{array}{l}\text { Criteria } \\
\mathbf{A}\end{array}$} & \multicolumn{2}{|c|}{ More important? } & \multirow{2}{*}{$\begin{array}{r}\text { Scale } \\
(1-9)\end{array}$} \\
\hline & & & B & A or B & \\
\hline 1 & 2 & \multirow[t]{7}{*}{ Geomorphology } & Lineament Density & A & 1 \\
\hline 1 & 3 & & Lithology & A & 2 \\
\hline 1 & 4 & & Average Slope & $\mathrm{A}$ & 7 \\
\hline 1 & 5 & & Aspect & $\mathrm{A}$ & 5 \\
\hline 1 & 6 & & Soil & $\mathrm{A}$ & 6 \\
\hline 1 & 7 & & LULC & $\mathrm{A}$ & 7 \\
\hline 1 & 8 & & Drainage Density & $\mathrm{A}$ & 8 \\
\hline 2 & 3 & \multirow[t]{6}{*}{ Lineament Density } & Lithology & A & 1 \\
\hline 2 & 4 & & Average Slope & A & 5 \\
\hline 2 & 5 & & Aspect & $\mathrm{A}$ & 4 \\
\hline 2 & 6 & & Soil & $\mathrm{A}$ & 3 \\
\hline 2 & 7 & & LULC & $\mathrm{A}$ & 2 \\
\hline 2 & 8 & & Drainage Density & $\mathrm{A}$ & 6 \\
\hline 3 & 4 & \multirow[t]{5}{*}{ Lithology } & Average Slope & A & 2 \\
\hline 3 & 5 & & Aspect & $\mathrm{A}$ & 6 \\
\hline 3 & 6 & & Soil & $\mathrm{A}$ & 4 \\
\hline 3 & 7 & & LULC & $\mathrm{A}$ & 5 \\
\hline 3 & 8 & & Drainage Density & $\mathrm{A}$ & 9 \\
\hline 4 & 5 & \multirow[t]{4}{*}{ Average Slope } & Aspect & $\mathrm{A}$ & 2 \\
\hline 4 & 6 & & Soil & A & 3 \\
\hline 4 & 7 & & LULC & $\mathrm{A}$ & 2 \\
\hline 4 & 8 & & Drainage Density & A & 5 \\
\hline 5 & 6 & \multirow[t]{3}{*}{ Aspect } & Soil & $\mathrm{A}$ & 2 \\
\hline 5 & 7 & & LULC & $\mathrm{A}$ & 2 \\
\hline 5 & 8 & & Drainage Density & $\mathrm{A}$ & 3 \\
\hline 6 & 7 & \multirow[t]{2}{*}{ Soil } & LULC & A & 5 \\
\hline 6 & 8 & & Drainage Density & $\mathrm{A}$ & 4 \\
\hline 7 & 8 & LULC & Drainage Density & $\mathrm{A}$ & 3 \\
\hline
\end{tabular}

Source: weightage assigned by authors based on Saaty's scale (1980, 1994, and 1996)

*Using AHP by K. D. Geopel version 15.09.2018 
Table 3 Assigned ranks of sub-classes of each conditioning factor

\begin{tabular}{|c|c|c|c|}
\hline Sl. No & Causative factors & Sub-classes & Rank \\
\hline \multirow[t]{10}{*}{1} & \multirow[t]{10}{*}{ Geomorphology } & Older Alluvial Plain & 4 \\
\hline & & Older Flood Plain & 3 \\
\hline & & Lateral Bar & 2 \\
\hline & & Pediment & 1 \\
\hline & & Pediplain & 1 \\
\hline & & Plain (Lateritic) & 3 \\
\hline & & Point Bar & 2 \\
\hline & & Upland (Lateritic) & 1 \\
\hline & & Valley Fill & 4 \\
\hline & & Water body & 5 \\
\hline \multirow[t]{5}{*}{2} & \multirow[t]{5}{*}{ Lineament density $\left(\mathrm{km} / \mathrm{km}^{2}\right)$} & Less than 0.3 & 5 \\
\hline & & $0.3-0.6$ & 4 \\
\hline & & $0.6-0.9$ & 3 \\
\hline & & $0.9-1.2$ & 2 \\
\hline & & Greater than 1.2 & 1 \\
\hline \multirow[t]{15}{*}{3} & \multirow[t]{15}{*}{ Lithology } & Biotite gneiss & 1 \\
\hline & & Ferruginour sandstone & 3 \\
\hline & & Gabbro & 2 \\
\hline & & Granite gneiss & 1 \\
\hline & & Hornblende gneiss & 1 \\
\hline & & Hornblende schist, amphibolite, meta ultrabasalt & 2 \\
\hline & & Laterite & 5 \\
\hline & & Lateritic soil & 5 \\
\hline & & Mica schist/schist & 2 \\
\hline & & Pegmatite & 1 \\
\hline & & Quartz toumaline rock & 2 \\
\hline & & Quartzite, cherty, quartize & 3 \\
\hline & & Sand, silt, clay, calcarious concentration & 5 \\
\hline & & Sand, silt, gravel (prasent day deposit) & 4 \\
\hline & & Yellowish brown fine sand, silt, clay & 4 \\
\hline \multirow[t]{5}{*}{4} & \multirow[t]{5}{*}{ Average slope in degree } & Less than 0.5 & 5 \\
\hline & & $0.5-1.2$ & 4 \\
\hline & & $1.2-1.9$ & 3 \\
\hline & & $1.9-2.6$ & 2 \\
\hline & & Greater than 2.6 & 1 \\
\hline \multirow[t]{10}{*}{5} & \multirow[t]{10}{*}{ Slope aspect } & Flat $(-1)$ & 5 \\
\hline & & North $(0-22.5)$ & 5 \\
\hline & & Northeast (22.5-67.5) & 4 \\
\hline & & East (67.5-112.5) & 4 \\
\hline & & Southeast (112.5-157.5) & 3 \\
\hline & & South (157.5-202.5) & 3 \\
\hline & & Southwest (202.5-247.5) & 2 \\
\hline & & West (247.5-292.5) & 2 \\
\hline & & Northwest (292.5-337.5) & 1 \\
\hline & & North (337.5-360) & 1 \\
\hline \multirow[t]{5}{*}{6} & \multirow[t]{5}{*}{ Soil types } & W093 & 5 \\
\hline & & W097 & 1 \\
\hline & & W098 & 2 \\
\hline & & W106 & 3 \\
\hline & & W107 & 4 \\
\hline 7 & LULC & Water body & 5 \\
\hline
\end{tabular}


Table 3 (continued)

\begin{tabular}{|c|c|c|c|}
\hline Sl. No & Causative factors & Sub-classes & Rank \\
\hline \multirow{9}{*}{8} & \multirow{9}{*}{ Drainage density $\left(\mathrm{km} / \mathrm{km}^{2}\right)$} & Vegetation cover & 2 \\
\hline & & Settlement & 1 \\
\hline & & Agricultural land & 3 \\
\hline & & Barren land & 4 \\
\hline & & Less than 0.2 & 5 \\
\hline & & $0.2-1.0$ & 4 \\
\hline & & $1.0-1.8$ & 3 \\
\hline & & $1.8-2.6$ & 2 \\
\hline & & Greater than 2.6 & 1 \\
\hline
\end{tabular}

Source: prepared by authors

Table 4 Pair-wise comparison matric for the AHP process

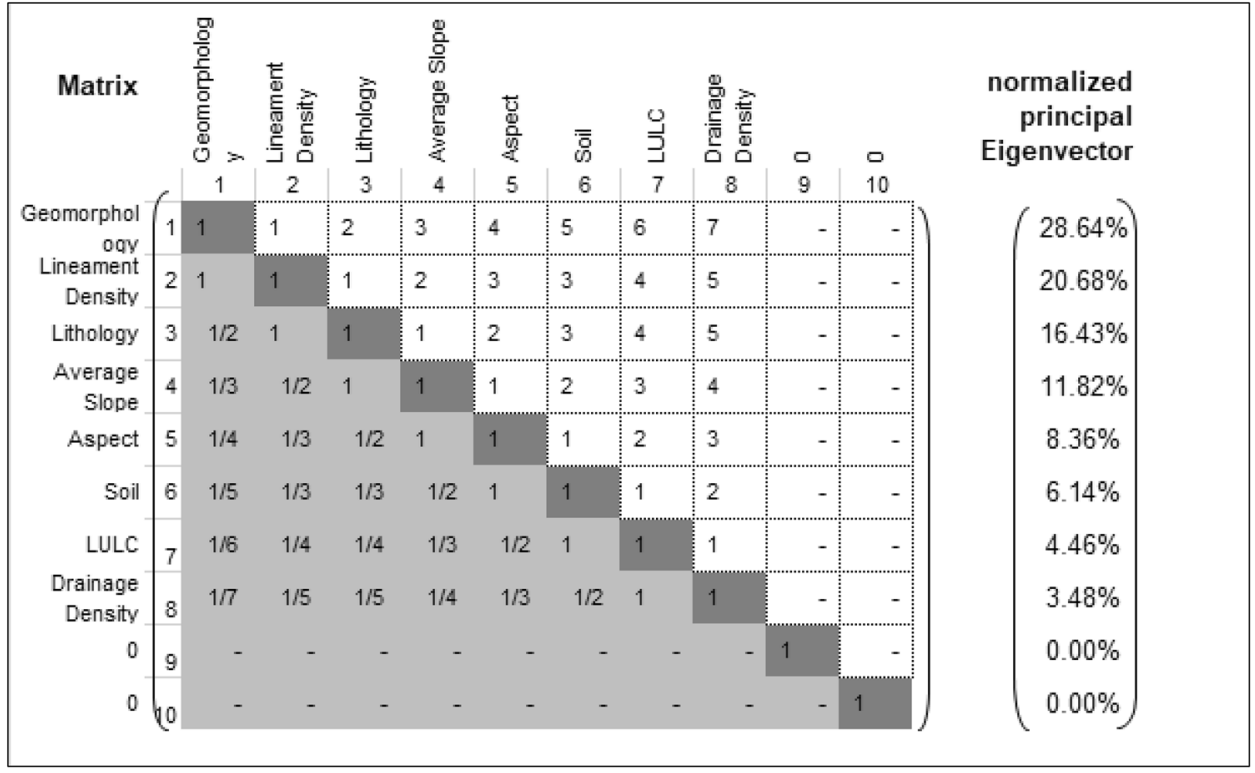

"Consistency ratio $=1.30 \%$, maximum acceptance level is $10 \%$ for more than 4 factors

*Using AHP by K. D. Geopel version 15.09.2018

Table 5 Details about the soil category with description

\begin{tabular}{lll}
\hline Sl. No & Soil category & Descriptions \\
\hline 1 & W093 & $\begin{array}{c}\text { Shallow, somewhat excessively drained, gravelly loamy soils occurring on gently sloping subdued ridges with gravelly } \\
\text { loamy surface and severe erosion } \\
\text { Very deep, imperfectly drained, fine soils occurring on very gently sloping to undulating plain with loamy surface and } \\
\text { moderate erosion }\end{array}$ \\
3 & W097 & $\begin{array}{c}\text { Very deep, moderately well-drained, fine loamy soils occurring on very gentle sloping to undulating plain with loamy } \\
\text { surface and moderate erosion } \\
4\end{array}$ \\
W106 & $\begin{array}{c}\text { Very deep, well-drained, fine loamy soils occurring on very gently sloping to undulating plateau with loamy surface and } \\
\text { moderate erosion } \\
\text { Very deep, well-drained coarse loamy soils occurring on very gently sloping valleys on undulating plateau with loamy } \\
\text { surface and moderate erosion }\end{array}$ \\
\hline
\end{tabular}

Source: NBSS and LUP, India 
Table 6 Calculated weightage of various controlling factors for creating the groundwater potential zones (GWPZ)

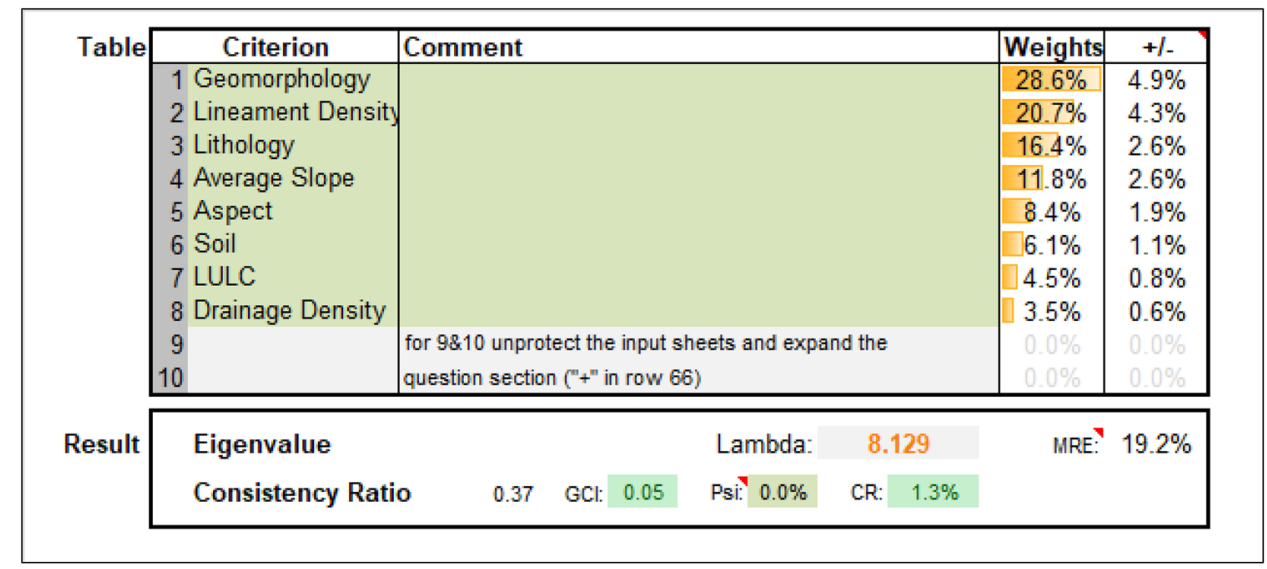

Source: calculated by authors

*Using AHP by K. D. Geopel version 15.09.2018 where CR denotes consistency ratio, $\mathrm{CI}$ indicates consistency index, $\mathrm{RI}$ is random index, $\lambda \max$ is principal eigenvalue in the matrix and $n$ is the number of parameters. In the present study, consistency ratio (CR) values are $1.30 \%$ means 0.013 which is lesser than the upper acceptance value $(0.10$ for more than 4 factors) stated by Saaty in 1980 (Tables 7 and 4).

\section{Weighted overlay model (WOM)}

The weighted overlay model is a simple, direct, and adequate methodology for evaluations of groundwater potential in a drought-prone area. In this study eight groundwater inducing factor maps were used for assessment of GWP mapping. To combine these in performing the analysis, each cell from each map layer had to be reclassified into a common preference scale (Saaty's scale). All thematic maps were integrated using WOM (Shit et al. 2016; Hammami et al. 2019; Das 2020).

$S=\frac{\sum W i S i j}{\sum W i}$

where $W_{i}$ is the weight of the $i^{\text {th }}$ factor map, Sij is the $i^{\text {th }}$ spatial class weight of the $j^{\text {th }}$ factor map, $S$ is the spatial unit value in the output map.

These weighted factor maps were integrated into the GIS environment using a weighted overlay analysis to prepare a GWPZ map (Fig. 4).

\section{Modelling for determining the groundwater potential zones}

The groundwater potential zones for the Bankura-I and II blocks were generated by overlapping multiple selected thematic layers that are likely to be contributing to groundwater occurrence based on GIS and the AHP technique (Table 6). The weighted integration technique was used to delineate the GWP areas based on Eq. 2 (Malczewski 1999; Muralitharan and Palanivel 2015; Bhattacharya et al. 2020; Das 2020).

GWPI $=\sum_{w=1}^{n} \cdot \sum_{j=1}^{n} W j \times X i$,

where $W j$ is considered as a normalized weight of the $j^{\text {th }}$ thematic layer and $X i$ is the rank associated with classes of ith thematic layer, $m$ indicates the number of total thematic layers used and $n$ denotes the total classes of thematic layers. Further, the modeling of GWPI was done based on the following Eq. 5, (Rao and Briz-Kishore 1991; Kumar et al. 2020; Berhanu and Hatiye 2020; Goitsemang et al. 2020),

$$
\begin{aligned}
\mathrm{GWPI}= & (\mathrm{GM} w \times \mathrm{GM} r)+(\mathrm{LD} w \times \mathrm{LD} r) \\
& +(\mathrm{LG} w \times \mathrm{LG} r) \\
& +(\mathrm{AS} w \times \mathrm{AS} r)+(\mathrm{SA} w \times \mathrm{SA} r) \\
& +(\mathrm{SL} w \times \mathrm{SL} r)+(\mathrm{LULC} w \times \mathrm{LULC} r) \\
& +(\mathrm{DD} w \times \mathrm{DD} r),
\end{aligned}
$$

where GM is geomorphology, LD is the lineament density, LG is the lithology, AS is the average slope, SA is the slope aspect, SL is soil type, LULC is the land use and land cover, and DD is the drainage density. Further, the subscripts ' $w$ ' and ' $r$ ' for each layer denote the AHP normalized weight and rank of each subclass.

Based on the above calculations, the entire study area was categorized into five zones of groundwater potential 
Table 7 Saaty's significance scale for assigning weight of parameters

\begin{tabular}{|c|c|c|}
\hline Intensity & Definition & Explanation \\
\hline 1 & Equal importance & Two elements contribute equally to the objective \\
\hline 3 & Moderate importance & Experience and judgement slightly favour one element over another \\
\hline 5 & Strong importance & Experience and judgement strongly favour one element over another \\
\hline 7 & Very strong importance & $\begin{array}{l}\text { One element is favoured very strongly over another, it dominance is } \\
\text { demonstrated in practice }\end{array}$ \\
\hline 9 & Extreme importance & $\begin{array}{l}\text { The evidence favouring one element over another is of the highest } \\
\text { possible order of affirmation }\end{array}$ \\
\hline
\end{tabular}

$2,4,6,8$ can be used to express intermediate value

viz.: "very poor"; "poor"; "moderate" "good"; and "very good" groundwater potential zones.

\section{Geo-environmental factors affecting groundwater potential (WGP)}

The extent to which groundwater will occur in any geologic and geomorphic setting will depend on both natural and anthropogenic factors. Based on the available literature, there are many conditioning factors that can influence groundwater availability. In the present study, eight parameters were considered to influence groundwater availability. These are: the lineament density; lithology; the average slope; the slope aspect; the soil type. Land use and land cover (LULC), and drainage density have been taken as conditioning factors to prepare groundwater potential map.

\section{Geomorphology}

Landscape features and surface structure are important for determining the groundwater potentiality (Ghosh et al.
2016; Murmu et al. 2019; Kumar and Krishna 2018). Both surface and sub-surface movement of water can be controlled by the topographic characteristics. Geomorphologically, the study area consists of: (1) older alluvial plain; (2) older flood plain; (3) lateral bar deposits; (4) pediment; (5) pediplain; (6) lateritic plain; (7) point bar deposits; (8)lateritic upland; (9) valley fill deposits; and (10) surface water bodies (Fig. 5a). The Damodar and Dwarkeswar rivers are the dominant waterways within the study area. Additionally, there are a few narrow channels and natural and anthropogenic water bodies in the study area (for example, the Saheb pukur pond, Lal bandh, the Kuch kuchia pond, Nutan pukur, Jamuna bandh and Gosai bandh). In total, an area of about $11.98 \mathrm{~km}^{2}$ is covered bu water bodies in the study area. Pediplain is the dominant geomorphological feature that exists throughout the study area $\left(245.05 \mathrm{~km}^{2}\right.$, $58 \%$ spatial coverage). Valley-fill deposits are generally unconsolidated alluvial and colluvial materials consisting of sand, silt, gravels, pebbles, etc., deposited along the floor of a stream valley. This type of landform is mostly present along with the major river systems of the study area with a width of 1-2 km. A small portion of the blocks (Bankura-I
Fig. 4 Purpose of using groundwater to fulfil their basic need. Source: primary survey, 2021

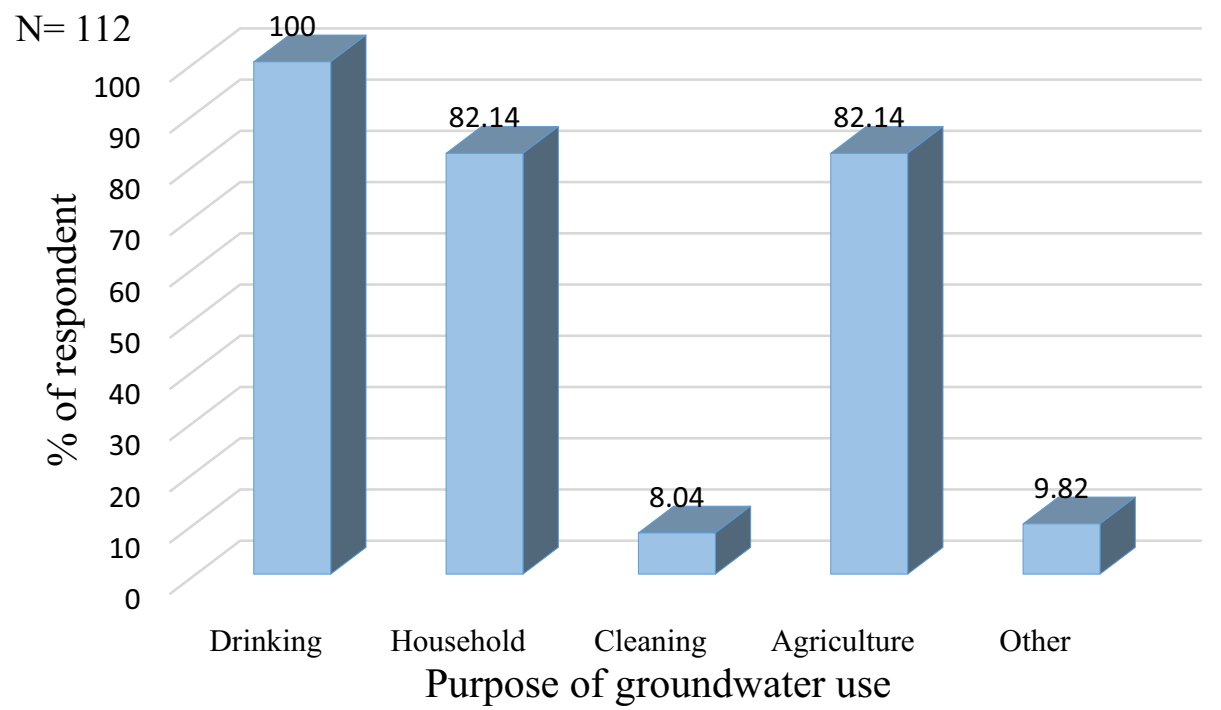



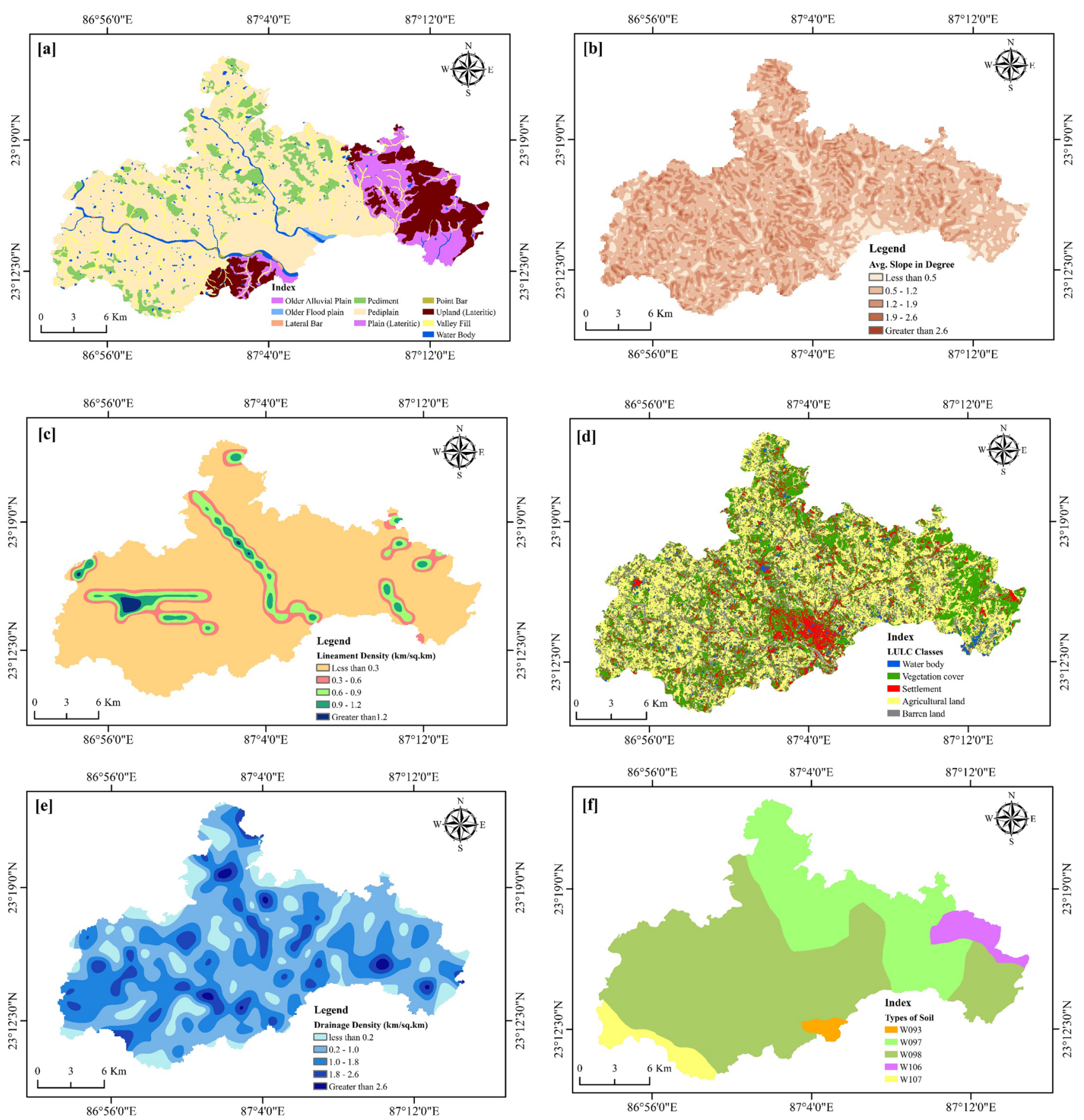

Fig. 5 Controlling factors of the Groundwater Potential zones. (a) Geomorphology, (b) average slope, (c) lineament density, (d) land use and land cover (e), drainage density (f), soil (g), lithology, (h) aspect

and II) consists of deep or moderately buried pediments. These pediments are covered with thick weathered materials in the north and the south-western part of the study area as small patches $\left(40.71 \mathrm{~km}^{2}\right)$. Other important geomorphological features are plains (lateritic) and upland (lateritic) plains they comprise about $36.05 \mathrm{~km}^{2}$ and $47.66 \mathrm{~km}^{2}$ of the geographical area, respectively.

\section{Lineament density}

Lineaments are as the linear or curvilinear surface expression of structural features in underlying bedrock, including faults, cleavages, fractures, and other surfaces of discontinuity (O'Leary et al. 1976; Yeh et al. 2008), that can regulate groundwater accumulation (Roy et al. 2021). Because the existence of lineaments generally implies a permeable 

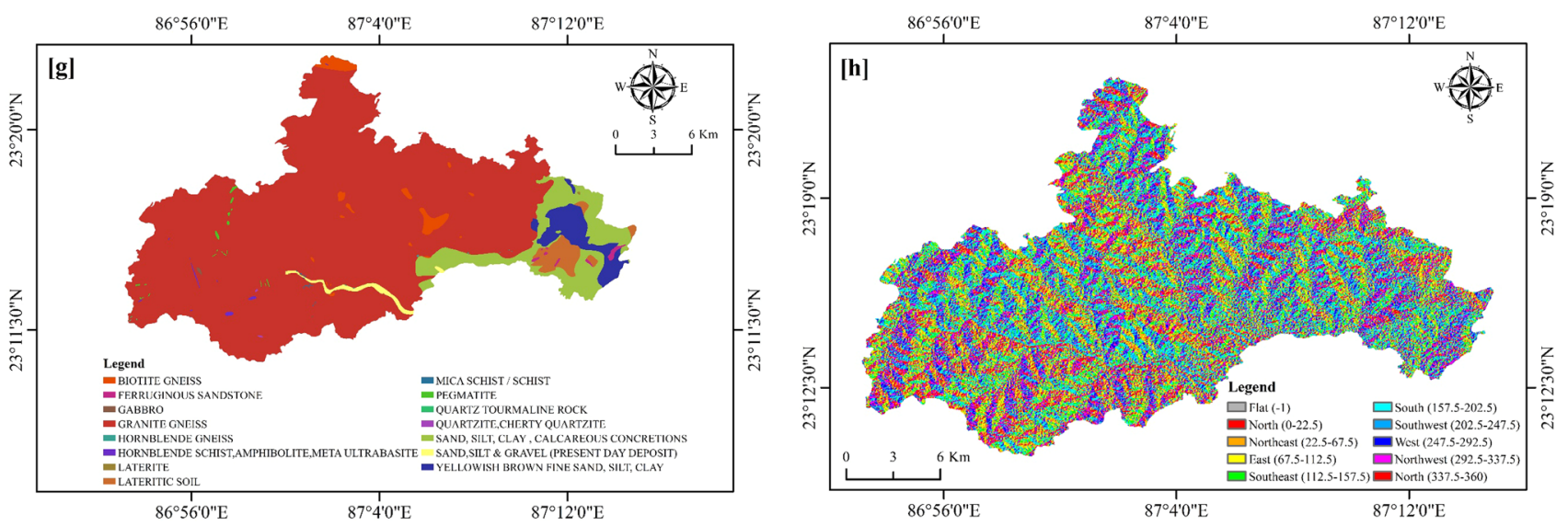

Fig. 5 (continued)

zone, the density of lineaments in each region can immediately disclose the groundwater potential (Saranya and Saravanan 2020). Lattman and Parizek (1964) were the first to adopt a lineaments map to exploit groundwater. Following that, several researchers have used this method in difficult geological locations. High secondary porosity is inferred from a substantial lineament-length density, suggesting a zone with high groundwater potential (Yeh et al. 2008). In the present study area of the Bankura drought-prone region, the lineament density varies from 0 to $1.4 \mathrm{~km} / \mathrm{km}^{2}$ and can be divided into five classes viz. less than $0.3 \mathrm{~km} / \mathrm{km}^{2}, 0.3-0.6 \mathrm{~km} / \mathrm{km}^{2}, 0.6-0.9 \mathrm{~km} / \mathrm{km}^{2}$, $0.9-1.2 \mathrm{~km} / \mathrm{km}^{2}$, and greater than $1.2 \mathrm{~km} / \mathrm{km}^{2}$ (Fig. $5 \mathrm{c}$ ). The central part of Bankura-I and the eastern and western part of Bankura-II block have the highest density of lineament-lengths, which means that these areas are more likely to be prospective for groundwater than other parts of the study area. However, most of the study area has a negligible density of lineaments.

\section{Lithology}

Generally, the lithology of bedrock influences the porosity and permeability of materials in the overlying weathered profile that comprises regolith in many areas (Chowdhury et al. 2010) which, in turn, affects the specific storage of groundwater recharge. The lithology of bedrock also influences the extent to which water can be stored and will be transmitted in basement rock materials beneath the regolith (Singh et al. 2013; Abijith et al. 2020). In the study area,

Table 8 Details about the lithologic units with formation

\begin{tabular}{|c|c|c|c|c|}
\hline S1. no & Age & Group name & Formation & Lithologic \\
\hline 1 & Pleistocene & Older alluvium & Lalgarh & Lateritic soil \\
\hline 2 & Proterozoic & Chhotanagpur gneissic complex & & Hornblende gneiss \\
\hline 3 & Meghalayan & Newer alluvium & Hoogly & Sand, silt and gravel (present day deposit) \\
\hline 4 & Archaean- palaeo-proterozoic & Unclassified metamorphics & & Hornblende schist, amphibolite, meta ultrabasite \\
\hline 5 & Proterozoic & & & Pegmatite \\
\hline 6 & Pleistocene-holocene & Older alluvium & Sijua & Sand, silt, clay, calcareous concretions \\
\hline 7 & Holocene & Newer alluvium & Panskura & Yellowish brown fine sand, silt, clay \\
\hline 8 & Proterozoic & Chhotanagpur gneissic complex & & Granite gneiss \\
\hline 9 & Proterozoic & Chhotanagpur gneissic complex & & Biotite gneiss \\
\hline 10 & Proterozoic & & & Gabbro \\
\hline 11 & Cenozoic & & & Laterite \\
\hline 12 & Proterozoic & & & Quartz tourmaline rock \\
\hline 13 & Archaean- palaeo-proterozoic & Unclassified metamorphics & & Mica schist/schist \\
\hline 14 & Cenozoic & & & Ferruginous sandstone \\
\hline 15 & Palaeo-Proterozoic & Singhbhum & & Quartzite, cherty quartzite \\
\hline
\end{tabular}

Source: geological survey of India (GSI) 
fifteen lithologic units have been identified, with granite gneisses being the most important basement rocks (with an area of $355.58 \mathrm{~km}^{2}$, or a spatial coverage of about $84 \%$ of the study area). Other geological materials that have been mapped in the study area are: (1) shallow regolith comprising sands, silts, clay sand calcareous concretions; (2) yellowish brown fine sands, silts, and clays; (3) lateritic soil; (4) biotite gneiss; and (5) recent alluvial sediments consisting of sands, silts and gravels). They comprise about $34.04 \mathrm{~km}^{2}$, $13.33 \mathrm{~km}^{2}, 7.84 \mathrm{~km}^{2}, 5.81 \mathrm{~km}^{2}$, and $3.12 \mathrm{~km}^{2}$, respectively. Out of the total geographical area and can influence groundwater availability. Further details about the different lithologic units are presented in Table 8.

\section{Average slope}

The steepness of the land slope can directly control the rate that in incident rainfall can infiltrate through the soil profile and recharge groundwater. A steeper slope results in more surface runoff and lower groundwater recharge due to insufficient time to percolate into the soil profile, and so there is always an inverse connection between surface water infiltration and slope (Ghosh et al. 2020; Rajasekhar et al. 2019; Murmu et al. 2019; Roy et al. 2021). On the other hand, almost flat and gentle slope gradients have a good prospect for groundwater recharge as there is sufficient time to allow surface water to infiltrate into a soil profile and reach the water table.

The study area has been categorized into five distinct slope zones viz.: $<0.5$ degrees (covering an area of $\left.62.85 \mathrm{~km}^{2}\right) ; 0.5-1.2^{\circ}$ (covering an area of $230.51 \mathrm{~km}^{2}$ ), $1.2-1.9^{\circ}$ (covering an area of $101.56 \mathrm{~km}^{2}$ ); $1.9-2.6^{\circ}$ (covering an area of $7.53 \mathrm{~km}^{2}$ ); and $>2.6^{\circ}$ (covering an area of $0.06 \mathrm{~km}^{2}$ ). Based on the spatial coverage, $72.34 \%$ (the "very low" to "low" slope gradient zones) of the total geographical area is suitable for significant groundwater recharge (Fig. 5b).

\section{Slope aspect}

The slope aspect influences the amount of water that that is available for infiltration due to impacts on local soil water balances (Ercanoglu and Gokceoglu 2002). In this study, the slope aspect layer was extracted from GSI shapefile layers and divided into ten classes, including nine directions and one flat class (Fig. 5h). It is noteworthy that around $14.95 \mathrm{~km}^{2}$ area was classified as having a flat slope aspect, which has a positive influence on groundwater recharge.

\section{Soil type}

Soil data is routinely and widely used in groundwater recharge and vulnerability studies (Vias et al. 2005;
Samadder et al. 2011; Mokadem et al. 2018). This is because soil permeability is proportional to effective porosity, grain shape and size, and void ratio, implying that soil type has a significant impact on infiltration. Simply stated that sandyand gravelly textured soils have a higher infiltration potential, whereas clayey- and silty-textured soils have a lower infiltration capacity (Das and Paul 2015; Brady 1984). Permeability is likely to be modest in fine sands and loamy soils. In the present study area, there have been identified five types of soil viz. W093, W097, W098, W106, and W107. For details about the soil types, see the National Bureau of Soil Survey and Land Use Planning (NBSS and LUP) map sheets of West Bengal (Sheet 1-4). About $261.50 \mathrm{~km}^{2}$ $(61.93 \%)$ and $123.07 \mathrm{~km}^{2}(29.15 \%)$ of the study area was classified as having W098 and W097 soil types, respectively, which cover a larger portion of the study area. Additionally, areas of $4.86 \mathrm{~km}^{2}, 15.59 \mathrm{~km}^{2}$, and $17.21 \mathrm{~km}^{2}$ are covered by the W093, W106, and W107 soil categories respectively in the study area (Fig. 5f). For details about the characteristics of different soil categories are represented in Table 5.

\section{LULC}

Groundwater is primarily connected with the landscape and land use. LULC alteration can directly influence the groundwater recharge. The natural landscape is ideal for balance but artificial settings (e.g., by landscape modification in built-up areas, paved surfaces, deforestation, excessive use of groundwater, etc.), can cause declines in groundwater levels (Lerner and Harris 2009; Mishra et al. 2015). LULC was included in this study as an important factor affecting the groundwater.

It is noteworthy that groundwater recharge rates are lower in places with deep-rooted vegetation, such as trees also known as forest cover, than in areas with shallow-rooted vegetation, such as annual crops (Gee et al. 1992; Keese et al. 2005). The conversion from natural vegetation to controlled land use types frequently results in a one or two order of magnitude rise in recharge rates (Scanlon et al. 2006). Several factors influence the response of water resources to LULC change, including the original vegetation to be replaced, the vegetation that is replacing it, whether the change is permanent or temporary, and whether the changes are linked to land management practises involving drainage network changes (Scanlon et al. 2007). That's why LULC was included in this study as an important factor affecting the groundwater. In this study, LULC has been categorized into five LULC classes' viz. water bodies, vegetation cover, settlements, agricultural land, and barren land. About $40.51 \%$ of the total area is under vegetation cover, $9.21 \%$ under agricultural land, 29.95\% under barren land, 9.52\% under settlements, and the remaining $17.84 \%$ constitutes 
water bodies (Fig. 5d). In some of cases, agricultural land and water bodies receive a high ranking due to their ongoing recharge capacity, whereas settlement areas receive a poor ranking due to their worsening influence on groundwater capacity (Ghosh et al. 2016; Roy et al. 2021).

\section{Drainage density}

The form and structure of the bedrock, the kind of vegetation, the rainfall absorption capacity of soils, infiltration, and slope gradient all influence the drainage system of a given location (Rahmati et al. 2015). Generally, more infiltration and less surface runoff takes place in low-drainage-density areas. It indicates that low-drainage-density locations can be conducive to groundwater development. Based on the surface drainage density, the study area can be grouped into five classes: $<0.2$ ("very low"), 0.2-1.0 ("low"), 1.0-1.8 ("moderate"), 1.8-2.6 ("high"), and $>2.6$ ("very high") km/km², as shown in Fig. 5e. The very high drainage density (2.81 $\mathrm{km}^{2}$ ) is scattered over the study area. The low and moderate drainage densities cover most of the study area $\left(195.01 \mathrm{~km}^{2}\right.$ and $132.01 \mathrm{~km}^{2}$ ).

\section{Ground truth validation of the GWPZ map}

Whenever possible, the output from a groundwater potential mapping exercise should be validated with information obtained from the mapped area. One of the most significant components of any multi-criteria decision making (MCDM) methodology is assessing the precision of the output models.

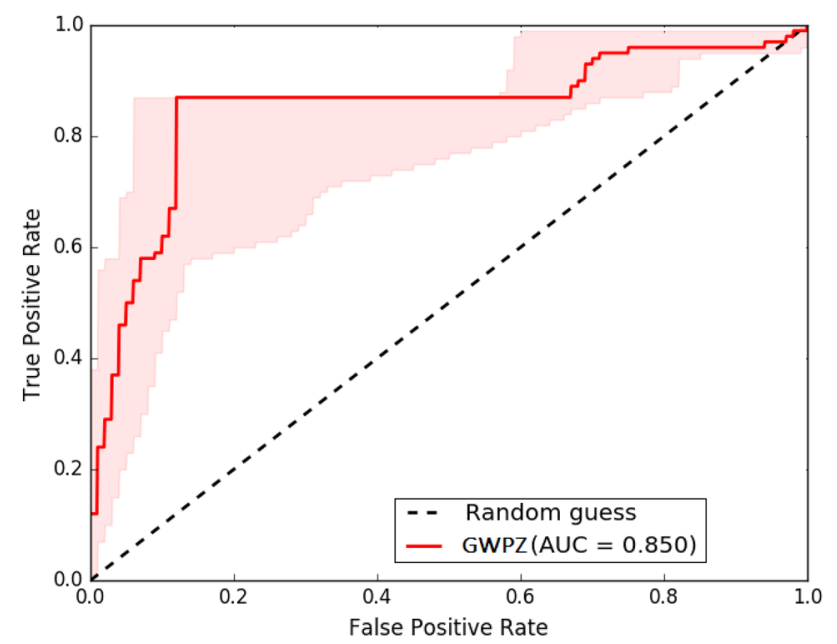

Fig. 6 ROC curve and AUC value analysis for validating the groundwater potential zones map. With the help of 105 groundwater sample stations (i.e., wells and tube wells), the results demonstrate a very good degree of satisfaction $(\mathrm{AUC}=0.850,85.00 \%$ )
Because of its simple nature, comprehensiveness, and reasonable agreement with the forecast, the area under the curve (AUC) based on inventory data (groundwater level data at various sample stations) is a well-established measure for validating such MCDM models (Pourghasemi et al. 2012; Tehrany et al. 2013; Das 2020). A value of 1 under the area indicates the highest level of accuracy without any bias. AUC values greater than 0.7 are generally regarded as acceptable discrimination and, as a result, acceptable models.

In this research work, the AHP-based GWPZ map was divided into five classes. A total of 105 groundwater monitoring sites (wells) were selected as sample points to validate the GWPZ map. The number of possible groundwater points for each class was determined by comparing the flood inventory points to the output groundwater potential zone map. Here, all the processes have been executed in the GIS environment using the ArcSDM tool. For calculating the ROC curve and AUC value, a GWPZ map in raster format was initially used as a classification model with inventory points in a GIS environment. This allowed a ROC curve and an AUC value to be produced in a PNG format (Fig. 6).

The high AUC value (0.850) indicates that groundwater potentiality mapping in the drought-prone Bankura-I and II blocks is quite precise (Das 2020), which could be useful for managing, controlling, planning, and reducing future vulnerability with high confidence.

\section{Primary data collection process to understand how groundwater is utilised by communities in the study area}

Field studies are an important part of research because they help to make the connection between the theoretical knowledge with actual behaviours of water use in the crisis and allowing researchers to better comprehend the real-world circumstances (Kandamby 2018; Kundu 2019). Due to the current COVID-19 epidemic and lockdown, a predesigned and organised questionnaire was implemented through an internet platform to acquire the information regarding the availability, facilities, and condition of groundwater in the Bankura I and Bankura II blocks. The descriptive survey was conducted among 112 respondents from the different functional groups of Bankura I and Bankura II. The study is based on both qualitative and quantitative data. The surveyed data were tabulated in various tables and visually presented using several cartographic techniques including bar diagrams, pie graphs, and figures. Specific statistical and quantitative techniques including factor analysis (FA) with the Likert scale test have been used to find out the importance of the parameters. 
Table 9 Details about the primary data collection process

\begin{tabular}{|c|c|c|c|c|c|}
\hline $\begin{array}{l}\text { Sample } \\
\text { blocks }\end{array}$ & $\begin{array}{c}\text { Total } \\
\text { no. of } \\
\text { Village }\end{array}$ & $\begin{array}{c}\text { Sample } \\
\text { household }\end{array}$ & $\begin{array}{c}\text { Purpose of Data } \\
\text { collection }\end{array}$ & $\begin{array}{c}\text { Methods of } \\
\text { data collection }\end{array}$ & Target group \\
\hline \multirow[t]{2}{*}{$\begin{array}{c}\text { Bankura } \\
\text { I, } \\
\text { Bankura } \\
\text { II }\end{array}$} & \multirow[t]{2}{*}{352} & \multirow[t]{2}{*}{112} & \multirow{2}{*}{$\begin{array}{l}\text { To know the situation } \\
\text { of water status and } \\
\text { safe drinking water } \\
\text { scarcity and examines } \\
\text { communities' } \\
\text { perception of the local } \\
\text { people. }\end{array}$} & $\begin{array}{l}\text { Google form } \\
\text { survey } \\
\text { (Questionnaire) } \\
\text { Phone call } \\
\text { survey }\end{array}$ & Villagers \\
\hline & & & & Observation & $\begin{array}{l}\text { Administrative } \\
\text { Household }\end{array}$ \\
\hline
\end{tabular}

Source: Prepared by authors

\section{Factor analysis using the Likert scale}

Likert (1932) initially proposed the Likert scale which is used to measuring attitudes or opinions based on an odd-numbered response set with possibilities or perceptions such as "strongly approve," "somewhat approve," "no idea," "somewhat disagree," and "strongly dislike." Using Principal Component Analysis (PCA) in popular social one of the most common approaches to perform factor analysis is to use science software such as SPSS (FA). In this study, factor analysis (FA) was used to assess the responses of different information which were collected through the questionnaire based on the Likert scale. Attribute variables with the response on a 1-5 scale (e.g., better condition, good, moderate, low, poor condition, etc.) (Yong and Pearce 2013) were assessed (see Table 9).

\section{Results and discussion}

\section{Groundwater potential (GWP) status in Bankura I and Bankura II blocks}

The preparation of a groundwater potential map is one of the most important measures that can be undertaken in a groundwater assessment in a region. The groundwater potential zone (GWPZ) map of the Bankura-I and BankuraII blocks that was produced in this study is shown in Fig. 7. In this map, the total geographical area of the district has been categorized into five distinct groundwater potential zones. These are: "very poor", "poor", "moderate", "good", and "very good" groundwater potential zones which were derived through the MSDM-AHP semi-controlled GIS application. Details of these groundwater potential zones are summarized in Table 10. The output map indicates that much of the Bankura-I and Bankura-II blocks has only a poor to moderate groundwater potential. Considering the total spatial coverage of the study area, about $0.68 \mathrm{~km}^{2}$ $(0.17 \%)$ has a very poor groundwater potential, while an area of about $0.27 \mathrm{~km}^{2}(0.07 \%)$ is mapped as having a very good potential for groundwater occurrence. Similarly, $250.57 \mathrm{~km}^{2}$ (62.26\%), $130.74 \mathrm{~km}^{2}(32.48 \%)$ and $20.20 \mathrm{~km}^{2}(5.02 \%)$ of the study area is mapped as having a poor, moderate, and good potential for groundwater potential, respectively.

The area mapped as having a "good" potential for significant groundwater occurrence is distributed in the eastern part of the Bankura-II block and near to the active river course as well as near water bodies. These areas are situated where there are lateritic plains, old alluvial deposits, areas gentle slopes, areas with agricultural activity, areas with barren land, and moderately well-drained soils which are conducive factors for increasing water infiltration. The moderate groundwater potential zones, on the other hand, are found in areas where soils have a much lower infiltration capacity.

Much of the study area is underlain by granitic basement rocks overlain by a clayey weathered profile which is mapped as having a low to moderate groundwater potential. Consequently, there are several villages (i.e., 9, 29, 46, and 47 in Bankura-II: and 895, 899, 900, 901. 902, 903, and 930 in Bankura-I) in the study area that are likely to have limited prospects for obtaining additional groundwater. 
Fig. 7 Present scenario of the groundwater potential zones at Bankura-I and Bankura-II blocks based on AHP model. Most of the spatial extension is covered with poor condition of groundwater potential

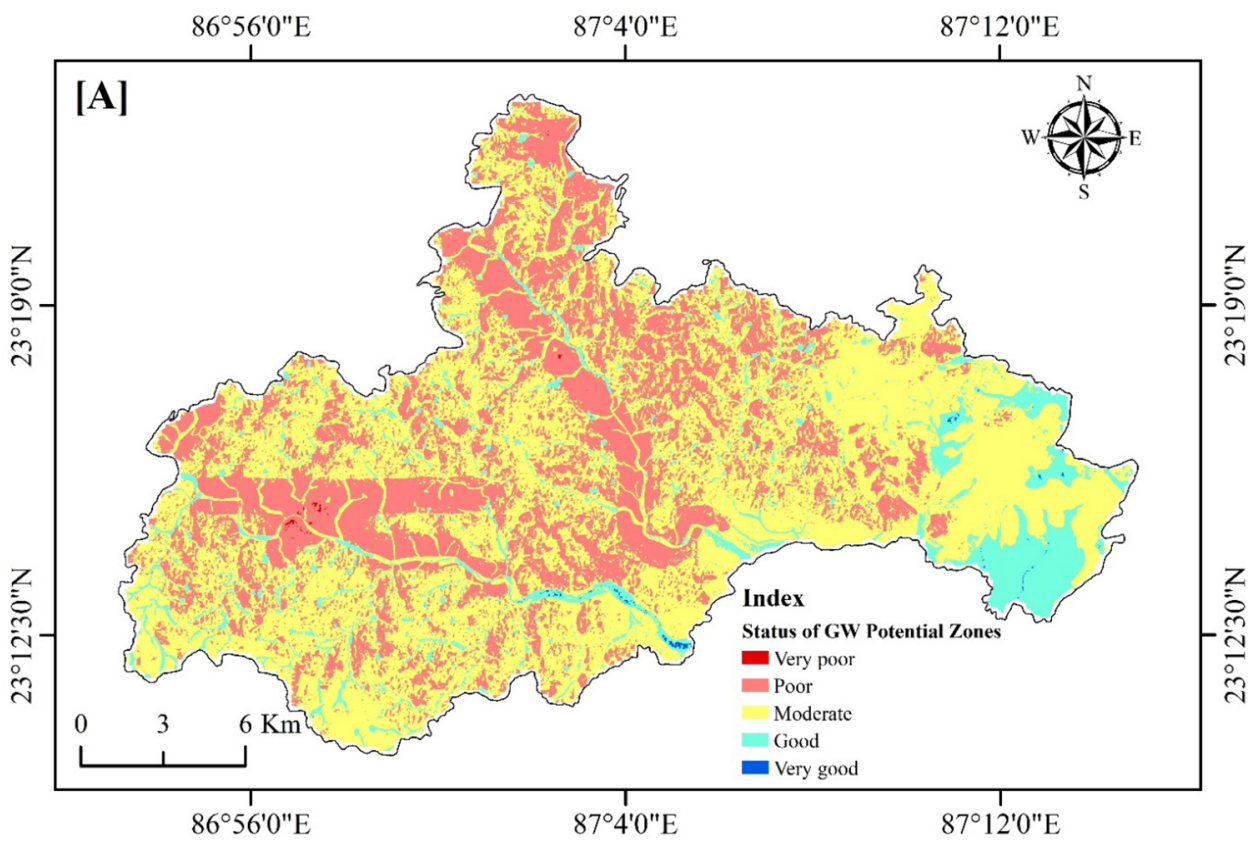

\begin{tabular}{|c|c|c|c|}
\hline S1. No. & GWPZ* & Area $\left(\mathrm{km}^{2}\right)$ & Remarks \\
\hline 1 & Very poor & 0.68 & - Very poor GWP villages $-9,29,46 \& 47$ \\
\hline 2 & Poor & 250.57 & (Bankura-II); 895, 899, 900, 901. 902, $903 \&$ \\
\hline 3 & Moderate & 130.74 & 930 (Bankura-I) \\
\hline 4 & Good & 20.20 & - Very good GWP villages $-1 \& 2$ (Bankura-I); \\
\hline 5 & Very Good & 0.27 & $64,149,157,159 \& 160$ (Bankura-II) \\
\hline
\end{tabular}

Source: calculated by authors

*GWPZ - Groundwater Potential Zone
Table 10 Spatial coverage and village distribution under five groundwater potential zones

\section{Status of groundwater use in the study area}

The water level of the Bankura-I and Bankura-II blocks drop by about 1-2 m during the pre-monsoon season but in some sites may not show significant changes in the monsoon season despite heavy rainfall. Groundwater of the study area is mostly used for agriculture and domestic purposes (Fig. 4). The respondent's choice of groundwater use is based on their basic need, and it depends on the use of water for a particular purpose. The results of the questionnaire indicated that $82.14 \%$ of respondent utilized groundwater for household purposes only. As the Bankura district is a droughtprone area, agriculture highly dependent on groundwater. Consequently, nearly $82.14 \%$ of the respondents supported that groundwater was mainly used for agriculture, cleaning, and other purposes. According to the questionnaire, nearly $82.85 \%$ of respondents observed the level of groundwater is declining and $7.15 \%$ noticed the change in water quality appearances (Table 11).
Table 11 Respondent views groundwater level and average depth from 2006 to 2016

Perception of groundwater level and average depth from 2006 to 2016

Types $\quad$ Hard rock area $\quad$ Respondent observation (\%)

Block covered Bankura-I, Water level Non-changeable Bankura-II fallen

\begin{tabular}{llll}
\hline Area in $\mathrm{km}^{2}$ & 391.9 & 92.85 & 7.15 \\
Average depth & $7-8 \mathrm{~m}$ & - & - \\
to water & & & \\
level & & &
\end{tabular}

Source: Surface Water Investigation Department (SWID), West Bengal and primary survey, 2021

\section{Availability of water and drinking water status}

West Bengal's water demand is constantly rising because of increased population and higher per-capita needs brought on 
Fig. 8 Water collecting from the different source by the respondent Source: primary survey, 2021

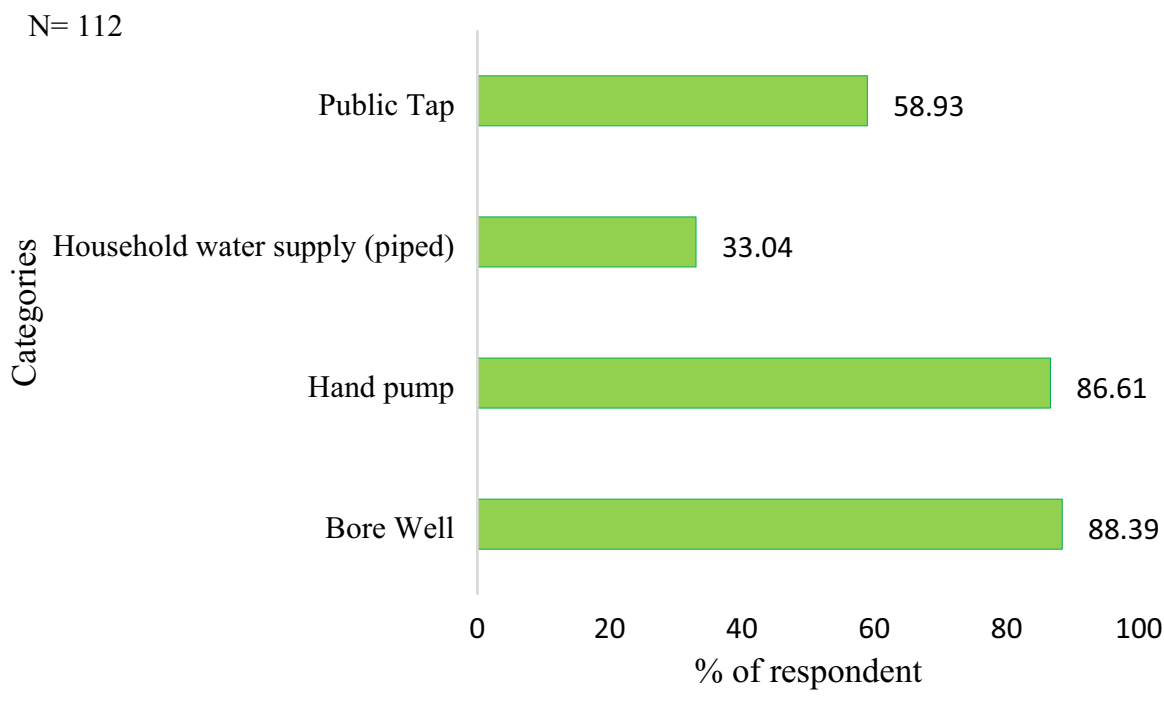

\section{Ground scenario of water use practices}

icy of 2002, which states that sufficient safe drinking water must be supplied to the whole population, both in urban and rural regions, where there is no other safe source of drinking water. This means that irrigation and multipurpose projects should always include a component to meet the drinking water demand, although this may also be met from other sources (Wang et al. 2012). This explains that, on average, households who pick surface water for their utilization, mostly collect them from the primary water sources. Apart from drinking and cooking, utility of water is necessary for all domestic uses (Prouty 2013. According to the UN, one-third of the world's population lives in water-scarce areas, with 1.1 billion people lacking access to safe drinking water (Shaw and Thaitakoo 2010).

Different types of sources of water availability in the study area have been shown in the Fig. 8. The results of the study indicated that respondents rely on hand pumps and bore wells 86.61 and $88.39 \%$, respectively. About $33.04 \%$ respondents received a piped water supply and $58.93 \%$ people are used public taps. The availability of surface water resources in the region appears to be declining due to siltation and large rainfall fluctuations. The respondents who drank tap water they said it was their primary source and it was the only safe option to them (Grothmann and Patt 2005). Rainwater, surface water, and borehole water were identified by many respondents as sources of drinking water. As the whole Bankura district lies under a drought-prone area so water scarcity is always high. Surface water supplied depend on the arrival of monsoonal rainfall. However, when the monsoon does arrive, the water from surface water sources is muddy and unsuitable to drink. When the wells and the river run drying the summer, life becomes difficult, and it is difficult to use water from other sources (see Fig. 8).
Multiple factors, including those related to climate change, threaten rural livelihoods in many parts of the world. People in rural areas adopt different traditional and modern methods to solve water scarcity, helps to increase water availability and help to fulfil their basic needs. It includes modifying food storage practices, modifying farming techniques, diversifying livelihoods, leveraging social networks, and adapting water management practices, etc (Yohannes et al. 2017).

Due to the detected groundwater depletion in the area, some of these alternatives must be proposed in the Bankura district (Chatterjee 2018). The District Development and Water Management Department of Bankura is trying to cope up the problems by arranging different programs such as the Backward Region Grant Fund, but these have yet to show clear results (BRGF 2013). Additionally, three significant surface waterbased supply initiatives are underway: the Barjora-Bankura I and Bankura II water supply schemes, the Hirabadh-Khatra and Ranibundh water supply system, and the Saltora-Chhatna water supply plan which may help to increase water availability.

The people of this village who are collecting water from the different sources they are using the boiling method to purify the water (Fig. 9). The quality of drinking water is one of the important indicators of living healthy. In case of the tap water nearly $43.21 \%$ of respondents are using boiling method to purify the water and a small percentage of a using boiling method as purifying methods resting that part most of the people are not using any methods as they directly using water for drinking. Nearly $0.98 \%$ of respondents are using aqua guards for purifying. On the other hand, as the people are facing scarcity of water, they are using several harvesting methods to store water (Lichtenthäler and Turton 


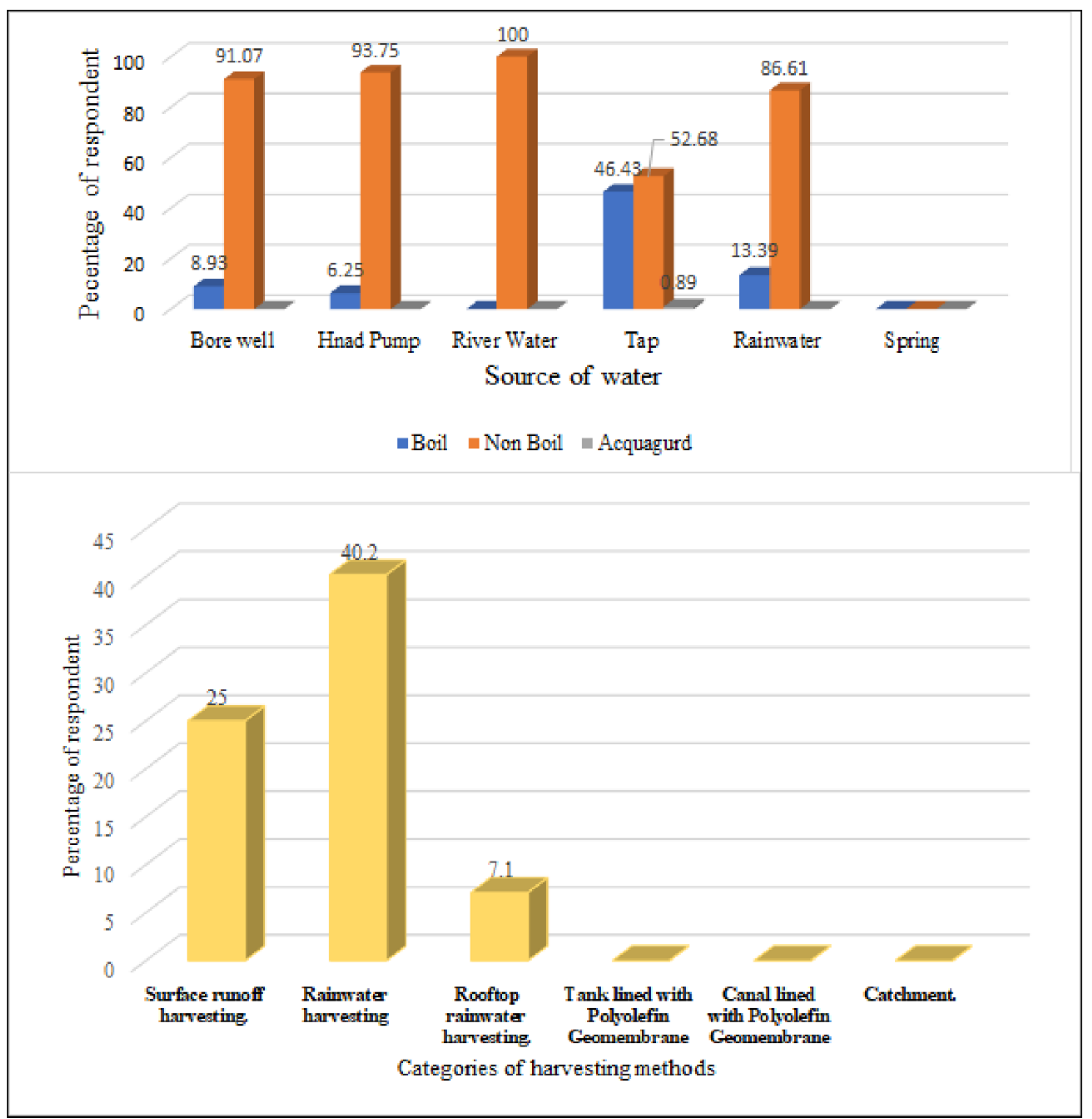

Fig. 9 Adaptation behaviour of respondent according to their needs and treatment process of the water before utilization

1999). Rooftop rainwater harvesting and surface runoff harvesting were employed by around $7.1 \%$ and $2.3 \%$ of respondents, respectively, to store the water (Fig. 9). Residents in the study areas are likely to use a variety of methods to obtain drinking water due to the general fluctuating pattern of water availability.

\section{Perception of respondents on water quality and availability}

People respond to threats they perceive, which is why risk perception is so important in risk management and behavioural change (Gbetibouo 2009; Maddison 2007). Risk perceptions have been found as a key factor in human behaviour (Fishbein and Ajzen 2011; Gbetibouo 2009; Grothmann and Patt 2005). Several approaches have been developed to understand risk perception and its impact on behaviour (Grothmann and Patt 2005).

In the Bankura district especially in Bankura I and Bankura II, groundwater levels fluctuate dramatically during the pre-monsoon and post-monsoon seasons, with water table fluctuations as high as $8.36 \mathrm{~m}$ being recorded in the area (Nag and Ghosh 2013). In general, the ground water quality in the area is suitable for potable use (Attari 2014) but is highly differ across the area.

The output is the table of commonalities which shows how much of the variance (i.e., the value of communality that must be more than 0.5 ) to be considered for further analysis. Otherwise, many variables would have to be removed from the factor 
Table 12 Factor analysis based on Likert scale regarding respondent's perception on groundwater condition and vulnerability

\begin{tabular}{|c|c|c|c|c|c|c|c|}
\hline \multicolumn{8}{|c|}{ Total variance explained } \\
\hline \multirow[t]{2}{*}{ Component } & \multicolumn{3}{|c|}{ Initial eigenvalues } & \multicolumn{4}{|c|}{ Extraction sums of squared loadings } \\
\hline & Total & $\%$ of Variance & Cumulative $\%$ & Total & $\%$ of Variance & Cumul & ve $\%$ \\
\hline 1 & 2.23 & 44.589 & 44.589 & 2.23 & 44.589 & 44.589 & \\
\hline 2 & 1.82 & 36.296 & 80.885 & 1.82 & 36.296 & 80.885 & \\
\hline 3 & 0.85 & 16.972 & 97.857 & - & - & - & \\
\hline 4 & 0.06 & 1.131 & 98.988 & - & - & - & \\
\hline 5 & 0.05 & 1.012 & 100 & - & - & - & \\
\hline \multicolumn{6}{|c|}{ Communalities } & Initial & Extraction \\
\hline \multicolumn{6}{|c|}{ Drinking water services } & 1 & 0.954 \\
\hline \multicolumn{6}{|c|}{ Water service for agriculture } & 1 & 0.247 \\
\hline \multicolumn{6}{|c|}{ Groundwater quality } & 1 & 0.954 \\
\hline \multicolumn{6}{|c|}{ Drinking water quality } & 1 & 0.954 \\
\hline \multicolumn{6}{|c|}{ Water management } & 1 & 0.935 \\
\hline
\end{tabular}

Extraction method: principal component analysis (PCA) analysis, the variables have been accounted for by the extracted factors. For instance, over $90 \%$ of the variance in "Groundwater quality, drinking water quality and water Management" is accounted for, while $24.7 \%$ of the variance in "Water service for agriculture" is accounted for. The table of Eigenvalue has been separated into three sub-sections, i.e., Initial Eigenvalues, Extracted Sums of Squared Loadings, and Rotation of Sums of Squared Loadings. Based on the table, the first factor accounts for $44.589 \%$ of the variance, the second $36.27 \%$, all the remaining factors are not significant (Table 12). Based on the above analysis the five key factors using the Likert scale such as drinking water services, water service for agriculture, groundwater quality, drinking water quality, indicate that the current water management system of Bankura district is not satisfactory to the people. According to the responders, the area is suffering several crises, including environmental issues, climate change, and water fragility, among others. The perception of the people on the above aspect is not satisfactory, it also supports that the people of Bankura are facing several problems with arranging or using the water from different sources.

\section{Conclusion}

The study area lies in Bankura district, a part of BankuraBishnupur rarh plains, under the state of West Bengal. The population in the study area is concentrated around the central part, mostly at and around the Bankura sadar. Agriculture dominated rural economy (besides pottery industry) is the backbone in the study area. Bankura Region is one of the most drought-prone areas in West Bengal. The area characterised by arid climate with annual average rainfall around $115 \mathrm{~mm}$ and which suffers from water stress and periodic uncertainty of supply.
The main geological units in the examined area are: Chhotanagpur gneissic complex, older alluvium, younger alluvium, and unclassified metamorphics. Proterozoic granite gneiss vastly covered the substrate of the study area. Therefore, red laterite surface soil is one of the triggering factors for cultivation. Geomorphologically, versatile landscapes in the study area cannot accentuate agricultural production. Damodar and Dwarkeswar Rivers are the dominant river within the study area and act as important groundwater recharge units. Nowadays, a total geographical area of the selected blocks (Bankura I and II) is experiencing different status of groundwater potential vis. very poor, poor, moderate, good, and very good groundwater potential based on MCDM-AHP model which is developed in a reliable GIS environment. But poor $\left(250.57 \mathrm{~km}^{2}\right.$ area) to moderate $\left(130.74 \mathrm{~km}^{2}\right)$ groundwater potential is dominating because of paucity of rainfall, dry climatic condition, unfavorable substrate characteristics and so on. However, groundwater table being a perfectly distinguishable seasonal undulating in nature which directly affects the residents as well as the natural environment. Furthermore, the ground water potential status of the Bankura-I and Bankura-II blocks is unsustainable, putting local inhabitants' everyday lives in jeopardy during the summer months. Low ground water tables impede not just the provision of drinking water, but also every element of human life, from economic to cultural aspects. In the study area, local groundwater is being used as a major source of water supply in the form of hand pump and bore wells. The usage of groundwater is linked to a variety of activities, including drinking, cleaning, cultivating, pottery industry, and other applications that means it has immense value. So, sustainable management of groundwater is not only important for present society, but also for future generations also. Water being an inseparable part of human life, the need for 
water in mother earth is rapidly increasing, owing to both rising population and higher per-capita needs brought on by economic expansion, to preserve natural resources (i.e., groundwater) is not our gaining knowledge rather primary duty.

People in rural regions employ several strategies to prepare for and adapt to water scarcity, including food storage, changing agricultural practices, diversifying livelihoods, leveraging social networks, and water management, among others. Several programs implemented in the area in the previous 5 years, particularly under the Backward Region Grant Fund (BRGF), have yet to bear fruit, even though the Bankura District Development and Water Management Department is attempting to deal with the situation by arranging various measures. Here, one surface water-based supply initiative is currently underway: the Barjora-Bankura I and Bankura II water supply schemes, which may help the entire blocks to provide sufficient water, despite the fact that the problem has worsened due to changes in climatic conditions and environment. Although groundwater shortage is the burning issue that is why sustainable management practices, e.g., rainwater harvesting, wastewater management, dry agricultural practices, formation of water reuse connectivity, etc., will be the best way to catch up energy to sustain. Finally, considering the foregoing facts about the importance of water, the effects of water scarcity, and sustainable water use, it is critical that people from all sections of the study area, as well as governmental and non-governmental organizations, collaborate in a holistic manner to secure water for future generations and protect the world's natural ecosystem. Also, this research might help policymakers and environmentalists develop an effective plan for sustainable groundwater exploitation and watershed protection, as well as provide recommendations to government authorities.

Acknowledgements The authors would like to thank NASA for the DEM, USGS for Landsat imageries, GSI for Geomorphology, and FAO for soil data set without which, it is not possible to find such novel results. Authors would like to be in-debt to local peoples who are provided information with sincere manner regarding to fulfill the study objectives. The authors also pay their sincere vote of thanks to their teachers of the Department of Geography and Applied Geography, University of North Bengal for building up the cognitive background to carry out such work. They are seriously thankful to the UGC for encouragement as Junior Reseach Fellow (JRF) to carry out the novel work. We also extent our thanks to Dr. Gunter Dörhöfer for his valuable comments and suggestion to improve the standard of our research work.

\section{Declarations}

Conflict of interest The authors declare that they have no known competing financial interests or personal relationships that could have appeared to influence the work reported in this paper and no other thirdparty interferences so far, their knowledge and belief.

\section{References}

Abedin MA, Habiba U, Shaw R (2014) Community perception and adaptation to safe drinking water scarcity: salinity, arsenic, and drought risks in coastal Bangladesh. Int J Dis Risk Sci 5(2):110 124. https://doi.org/10.1007/s13753-014-0021-6

Abijith D, Saravanan S, Singh L, Jennifer JJ, Saranya T, Parthasarathy KSS (2020) GIS-based multi-criteria analysis for identification of potential groundwater recharge zones-a case study from Ponnaniyaru watershed, Tamil Nadu, India. HydroResearch 3:1-14. https://doi.org/10.1016/j.hydres.2020.02.002

Ahmed N, Hoque MAA, Pradhan B, Arabameri A (2021) Spatio-temporal assessment of groundwater potential zone in the droughtprone area of Bangladesh using GIS-based bivariate models. Nat Resour Res. https://doi.org/10.1007/s11053-021-09870-0

Al Adaileh H, Al Qinna M, Barta K, Al-Karablieh E, Rakonczai J, Alobeiaat A (2019) A drought adaptation management system for groundwater resources based on combined drought index and vulnerability analysis. Earth Syst Environ 3(3):445-461. https:// doi.org/10.1007/s41748-019-00118-9

Attari SZ (2014) Perceptions of water use. Proc Natl Acad Sci 111(14):5129-5134. https://doi.org/10.1073/pnas.1316402111

Benjmel K, Amraoui F, Boutaleb S, Ouchchen M, Tahiri A, Touab A (2020) Mapping of groundwater potential zones in crystalline terrain using remote sensing, GIS techniques, and multicriteria data analysis (case of the Ighrem region, Western Anti-Atlas, Morocco). Water 12(2):471. https://doi.org/10.3390/w12020471

Berhanu KG, Hatiye SD (2020) Identification of groundwater potential zones using proxy data: case study of Megech watershed. Ethiop J Hydrol 28:100676. https://doi.org/10.1016/j.ejrh.2020.100676

Bhattacharya RK, Chatterjee ND, Das K (2020) An integrated GIS approach to analyze the impact of land use change and land cover alteration on ground water potential level: a study in Kangsabati Basin. India Groundw Sustain Develop 11:100399. https://doi.org/ 10.1016/j.gsd.2020.100399

Bhunia GS, Keshavarzi A, Shit PK, Omran ESE, Bagherzadeh A (2018) Evaluation of groundwater quality and its suitability for drinking and irrigation using GIS and geostatistics techniques in semiarid region of Neyshabur. Iran Appl Water Sci 8(6):1-16. https://doi.org/10.1007/s13201-018-0795-6

Brady NC (1984) The nature and properties of soil. Macmillan Publishing, New York

BRGF (2013) Backward regions grant fund (BRGF). Kanker, Chhattisgarh. Annual Plan-2012-2013. Accessed 15 june 2021

Census (2011) Primary census abstracts, registrar general of India. Ministry of Home Affairs, Government of India. Available at: http://www.censusindia.gov. Accessed 10 June 2021

Chatterjee U (2018) Water scarcity in semi-arid regions of Bankura district, West Bengal, India-problems and prospects. Khoj 5(1):87-96. https://doi.org/10.5958/2455-6963.2018.00007.3

Chowdhury A, Jha MK, Chowdary VM (2010) Delineation of groundwater recharge zones and identification of artificial recharge sites in West Medinipur district, West Bengal, using RS, GIS and MCDM techniques. Environ Earth Sci 59(6):1209-1222. https:// doi.org/10.1007/s12665-009-0110-9

Das S (2020) Flood susceptibility mapping of the Western Ghat coastal belt using multi-source geospatial data and analytical hierarchy process (AHP). Remote Sens Appl 20:100379. https://doi.org/10. 1016/j.rsase.2020.100379

Das K, Paul PK (2015) Soil moisture retrieval model by using RISAT1, C-band data in tropical dry and sub-humid zone of Bankura district of India. Egypt J Remote Sens Space Sci 18(2):297-310. https://doi.org/10.1016/j.ejrs.2015.09.004

Das S, Gupta A, Ghosh S (2017) Exploring groundwater potential zones using MIF technique in semi-arid region: a case study of 
Hingoli district. Maharashtra Spat Inform Res 25(6):749-756. https://doi.org/10.1007/s41324-017-0144-0

Dalin C, Wada Y, Kastner T, Puma MJ (2017) Groundwater depletion embedded in international food trade. Nature 543(7647):700-704. https://doi.org/10.1038/nature21403

Döll P, Mueller Schmied H, Schuh C, Portmann FT, Eicker A (2014) Global-scale assessment of groundwater depletion and related groundwater abstractions: combining hydrological modeling with information from well observations and GRACE satellites. Water Resour Res 50(7):5698-5720. https://doi.org/10.1002/ 2014WR015595

Ercanoglu M, Gokceoglu C (2002) Assessment of landslide susceptibility for a landslide-prone area (north of Yenice, NW Turkey) by fuzzy approach. Environ Geol 41(6):720-730. https://doi.org/10. 1007/s00254-001-0454-2

Fishbein M, Ajzen I (2011) Predicting and changing behavior: the reasoned action approach. Psychology Press

Gbetibouo GA (2009) Understanding farmers' perceptions and adaptations to climate change and variability: the case of the Limpopo Basin, South Africa, vol 849. International Food Policy Research Institute, Washington DC

Gee GW, Fayer MJ, Rockhold ML, Campbell MD (1992) Variations in recharge at the Hanford Site. Northwest Sci 66(4):237-250

Ghosh PK, Bandyopadhyay S, Jana NC (2016) Mapping of groundwater potential zones in hard rock terrain using geoinformatics: a case of Kumari watershed in western part of West Bengal. Model Earth Syst Environ 2(1):1. https://doi.org/10.1007/ s40808-015-0044-z

Ghosh D, Mandal M, Banerjee M, Karmakar M (2020) Impact of hydro-geological environment on availability of groundwater using analytical hierarchy process (AHP) and geospatial techniques: a study from the upper Kangsabati river basin. Groundw Sustain Dev 11:100419. https://doi.org/10.1016/j.gsd.2020. 100419

Ghosh R, Sutradhar S, Mondal P, Das N (2021) Application of DRASTIC model for assessing groundwater vulnerability: a study on Birbhum district, West Bengal. India Model Earth Syst Environ 7(2):1225-1239. https://doi.org/10.1007/s40808-020-01047-7

Gleeson T, Wada Y, Bierkens MF, Van Beek LP (2012) Water balance of global aquifers revealed by groundwater footprint. Nature 488(7410):197-200. https://doi.org/10.1038/nature11295

Gogu RC, Dassargues A (2000) Current trends and future challenges in groundwater vulnerability assessment using overlay and index methods. Environ Geol 39(6):549-559. https://doi.org/10.1007/ s002540050466

Grothmann T, Patt A (2005) Adaptive capacity and human cognition: the process of individual adaptation to climate change. Glob Environ Chang 15(3):199-213. https://doi.org/10.1016/j.gloen vcha.2005.01.002

Goitsemang T, Das DM, Raul SK, Subudhi CR, Panigrahi B (2020) Assessment of groundwater potential in the Kalahandi district of Odisha (India) using remote sensing, geographic information system and analytical hierarchy process. J Indian Soc Remote Sens 48(12):1739-1753. https://doi.org/10.1007/s12524-020-01188-3

Hammami S, Zouhri L, Souissi D, Souei A, Zghibi A, Marzougui A, Dlala M (2019) Application of the GIS based multi-criteria decision analysis and analytical hierarchy process (AHP) in the flood susceptibility mapping (Tunisia). Arab J Geosci 12(21):1-16. https://doi.org/10.1007/s12517-019-4754-9

Hazra S, Roy S, Mitra S (2017) Enhancing adaptive capacity and increasing resilience of small and marginal farmers of Purulia and Bankura districts, West Bengal to climate change. DRCSC Report 1-114

Hussein MT (2004) Hydrochemical evaluation of groundwater in the Blue Nile Basin, eastern Sudan, using conventional and multivariate techniques. Hydrogeol J 12(2):144-158
Kandamby T (2018) Enhancement of learning through field study. J Technol Sci Educ 8(4):408-419. https://doi.org/10.3926/jotse.403

Keese KE, Scanlon BR, Reedy RC (2005) Assessing controls on diffuse groundwater recharge using unsaturated flow modeling. Water Resour Res. https://doi.org/10.1029/2004WR003841

Kiker GA, Bridges TS, Varghese A, Seager TP, Linkov I (2005) Application of multicriteria decision analysis in environmental decision making. Integr Environ Assess Manag 1(2):95-108. https://doi. org/10.1897/IEAM_2004a-015.1

Kim G, Kim JS, Hwang DW (2011) Submarine groundwater discharge from oceanic islands standing in oligotrophic oceans: Implications for global biological production and organic carbon fluxes. Limnol Ocean 56(2):673-682

Kim SN, Lee WK, Shin KI, Kafatos M, Seo DJ, Kwak HB (2010) Comparison of spatial interpolation techniques for predicting climate factors in Korea. For Sci Technol 6(2):97-109. https://doi.org/10. 1080/21580103.2010.9671977

Konikow LF, Kendy E (2005) Groundwater depletion: a global problem. Hydrogeol J 13(1):317-320. https://doi.org/10.1007/ s10040-004-0411-8

Kumar A, Krishna AP (2018) Assessment of groundwater potential zones in coal mining impacted hard-rock terrain of India by integrating geospatial and analytic hierarchy process (AHP) approach. Geocarto Int 33(2):105-129. https://doi.org/10.1080/10106049.2016.1232314

Kumar VA, Mondal NC, Ahmed S (2020) Identification of groundwater potential zones using RS, GIS and AHP techniques: a case study in a part of Deccan volcanic province (DVP), Maharashtra, India. J Indian Soc Remote Sens 48(3):497-511. https://doi.org/10.1007/ s12524-019-01086-3

Kundu PK (2019) Role and importance of field study in geographical research. Res Rev Int J Multidiscip 4(5):2129-2132

Lattman LH, Parizek RR (1964) Relationship between fracture traces and the occurrence of ground water in carbonate rocks. J Hydrol 2(2):73-91. https://doi.org/10.1016/0022-1694(64)90019-8

Lerner DN, Harris B (2009) The relationship between land use and groundwater resources and quality. Land Use Policy 26:S265S273. https://doi.org/10.1016/j.landusepol.2009.09.005

Lichtenthäler G, Turton AR (1999) Water demand management, natural resource reconstruction and traditional value systems: a case study from Yemen. Occasional Paper No. 14. Water Issues Study Group, SOAS, University of London

Likert R (1932) A technique for the measurement of attitudes. Archives of Psychology

Ly S, Charles C, Degré A (2013) Different methods for spatial interpolation of rainfall data for operational hydrology and hydrological modeling at watershed scale: a review. Biotechnol Agron Soc Environ 17(2):392-406

Maddison D (2007) The perception of and adaptation to climate change in Africa. World Bank. https://doi.org/10.1596/1813-9450-4308

Magesh NS, Chandrasekar N, Soundranayagam JP (2012) Delineation of groundwater potential zones in Theni district, Tamil $\mathrm{Nadu}$, using remote sensing. GIS MIF Tech Geosci Front 3(2):189-196. https://doi.org/10.1016/j.gsf.2011.10.007

Malczewski J (1999) GIS and multicriteria decision analysis. John Wiley and Sons, Hoboken

Milly PCD (1994) Climate, soil water storage, and the average annual water balance. Water Resour Res 30(7):2143-2156. https://doi. org/10.1029/94WR00586

Mishra N, Khare D, Kumar S (2015) Impact of land use change on groundwater recharge in upper Ganga canal command. Int $\mathbf{J}$ Appl Eng Res 10(33):24284-24288

Mokadem N, Boughariou E, Mudarra M, Brahim FB, Andreo B, Hamed Y, Bouri S (2018) Mapping potential zones for groundwater recharge and its evaluation in arid environments using a GIS approach: case study of North Gafsa Basin (Central 
Tunisia). J Afr Earth Sc 141:107-117. https://doi.org/10.1016/j. jafrearsci.2018.02.007

Mukherjee A, Patil D (2013) Appraisal of use pattern in W Prone region F. J Appl Technol Environ Sanit 3(4):141-146

Muralitharan J, Palanivel K (2015) Groundwater targeting using remote sensing, geographical information system and analytical hierarchy process method in hard rock aquifer system, Karur district, Tamil Nadu. India Earth Sci Inform 8(4):827-842. https://doi.org/10.1007/s12145-015-0213-7

Murmu P, Kumar M, Lal D, Sonker I, Singh SK (2019) Delineation of groundwater potential zones using geospatial techniques and analytical hierarchy process in Dumka district, Jharkhand. India Groundw Sustain Develop 9:100239. https://doi.org/10.1016/j. gsd.2019.100239

Nag SK (1998) Morphometric analysis using remote sensing techniques in the Chaka sub-basin, Purulia district, West Bengal. J Indian Soc Remote Sens 26(1):69-76. https://doi.org/10.1007/ BF03007341

Nag SK, Ghosh P (2013) Delineation of groundwater potential zone in Chhatna Block, Bankura district, West Bengal, India using remote sensing and GIS techniques. Environ Earth Sci 70(5):2115-2127. https://doi.org/10.1007/s12665-012-1713-0

Nag SK, Kundu A (2016) Delineation of groundwater potential zones in hard rock terrain in Kashipur block, Purulia district, West Bengal, using geospatial techniques. Int J Waste Resour 6(201):1-13. https://doi.org/10.4172/2252-5211.1000201

Nag SK, Das S (2017) Assessment of groundwater quality from Bankura I and II blocks, Bankura district, West Bengal. India Appl Water Sci 7(6):2787-2802. https://doi.org/10.1007/ s13201-017-0530-8

O'leary DW, Friedman JD, Poh HA (1976) Lineament, linear, lineation: some proposed new standards for old terms. Geol Soc Am Bull 87(10):1463-1469. https://doi.org/10.1130/00167606(1976)87\%3C1463:LLLSPN\%3E2.0.CO;2

Ouyang Y, Wan Y, Jin W, Leininger TD, Feng G, Han Y (2021) Impact of climate change on groundwater resource in a region with a fast depletion rate: the Mississippi Embayment. J Water Clim Change. https://doi.org/10.2166/wcc.2021.326

Peters E, Van Lanen HAJ, Torfs PJJF, Bier G (2005) Drought in groundwater-drought distribution and performance indicators. J Hydrol 306(1-4):302-317. https://doi.org/10.1016/j.jhydrol. 2004.09.014

Pourghasemi HR, Mohammady M, Pradhan B (2012) Landslide susceptibility mapping using index of entropy and conditional probability models in GIS: Safarood Basin. Iran Catena 97:7184. https://doi.org/10.1016/j.catena.2012.05.005

Pramanik MK (2016) Site suitability analysis for agricultural land use of Darjeeling district using AHP and GIS techniques. Model Earth Syst Environ 2(2):56. https://doi.org/10.1007/s40808-016-0116-8

Prouty CM (2013) Socioeconomic factors' and water source features' affect on household water supply choices in Uganda and the associated environmental impacts. ProQuest LLC, University of South Florida, pp 1-95. http://scholarcommons.usf.edu/etd/4749

Rahmati O, Samani AN, Mahdavi M, Pourghasemi HR, Zeinivand H (2015) Groundwater potential mapping at Kurdistan region of Iran using analytic hierarchy process and GIS. Arab J Geosci 8(9):7059-7071

Rahmati O, Pourghasemi HR, Melesse AM (2016) Application of GISbased data driven random forest and maximum entropy models for groundwater potential mapping: a case study at Mehran region. Iran Catena 137:360-372. https://doi.org/10.1016/j.catena.2015. 10.010

Rajasekhar M, Raju GS, Sreenivasulu Y, Raju RS (2019) Delineation of groundwater potential zones in semi-arid region of Jilledubanderu river basin, Anantapur district, Andhra Pradesh, India using fuzzy logic, AHP and integrated fuzzy-AHP approaches. HydroResearch 2:97-108. https://doi.org/10.1016/j.hydres.2019.11.006

Rao BV, Briz-Kishore BH (1991) A methodology for locating potential aquifers in a typical semi-arid region in India using resistivity and hydrogeologic parameters. Geoexploration 27(1-2):55-64. https:// doi.org/10.1016/0016-7142(91)90014-4

Reddy PJR (2005) A text book of hydrology. Laxmi Publications (P) Ltd., New Delhi

Roy S, Hazra S, Chanda A, Das S (2020) Assessment of groundwater potential zones using multi-criteria decision-making technique: a micro-level case study from red and lateritic zone (RLZ) of West Bengal. India Sustain Water Resour Manag 6(1):1-14. https://doi. org/10.1007/s40899-020-00373-z

Roy S, Bose A, Mandal G (2021) Modeling and mapping geospatial distribution of groundwater potential zones in Darjeeling Himalayan region of India using analytical hierarchy process and GIS technique. Model Earth Syst Environ. https://doi.org/10.1007/ s40808-021-01174-9

Saaty TL (1980) The analytic hierarchy process: planning, priority setting, resource allocation. McGraw-Hill International Book Co., New York

Samadder RK, Kumar S, Gupta RP (2011) Paleochannels and their potential for artificial groundwater recharge in the western Ganga plains. J Hydrol 400(1-2):154-164. https://doi.org/10.1016/j.jhydr ol.2011.01.039

Saranya T, Saravanan S (2020) Groundwater potential zone mapping using analytical hierarchy process (AHP) and GIS for Kancheepuram district, Tamilnadu. India Model Earth Syst Environ. https://doi.org/10.1007/s40808-020-00744-7

Scanlon BR, Keese KE, Flint AL, Flint LE, Gaye CB, Edmunds WM, Simmers I (2006) Global synthesis of groundwater recharge in semiarid and arid regions. Hydrol Proces 20(15):3335-3370. https://doi.org/10.1002/hyp.6335

Scanlon BR, Reedy RC, Tachovsky JA (2007) Semiarid unsaturated zone chloride profiles: archives of past land use change impacts on water resources in the southern High Plains, United States. Water Resour Res. https://doi.org/10.1029/2006WR005769

Şener Ş, Sener E, Karagüzel R (2011) Solid waste disposal site selection with GIS and AHP methodology: a case study in SenirkentUluborlu (Isparta) Basin. Turk Environ Monit Assess 173(1):533554. https://doi.org/10.1007/s10661-010-1403-x

Senapati U, Das TK (2021) Assessment of basin-scale groundwater potentiality mapping in drought-prone upper Dwarakeshwar River basin, West Bengal, India, using GIS-based AHP techniques. Arab J Geosci 14(11):1-22. https://doi.org/10.1007/ s12517-021-07316-8

Shaw R, Thaitakoo D (eds) (2010) Water communities: introduction and overview, Chap 1. In: Water communities (community, environment and disaster risk management, vol 2. Emerald Group Publishing Limited, Bingley, pp 1-13. https://doi.org/10.1108/ S2040-7262(2010)0000002004

Shen Y, Oki T, Utsumi N, Kanae S, Hanasaki N (2008) Projection of future world water resources under SRES scenarios: water withdrawal/projection des ressources en eau mondiales futures selon les scénarios du RSSE: prélèvement d'eau. Hydrol Sci J 53(1):11-33. https://doi.org/10.1623/hysj.53.1.11

Shen Y, Chapelle FH, Strom EW, Benner R (2015) Origins and bioavailability of dissolved organic matter in groundwater. Biogeochemistry 122(1):61-78

Shit PK, Bhunia GS, Maiti R (2016) Potential landslide susceptibility mapping using weighted overlay model (WOM). Model Earth Syst Environ 2(1):21. https://doi.org/10.1007/s40808-016-0078-x

Singh P, Thakur JK, Kumar S (2013) Delineating groundwater potential zones in a hard-rock terrain using geospatial tool. Hydrol Sci J 58(1):213-223. https://doi.org/10.1080/02626667.2012.745644 
Sutradhar A, Chakrabortty D, Chattaraj M (2019) Identification of agricultural productivity regions and its major determinants: a case study from Bankura district, West Bengal. Int J Res Soc Sci 9(5):661-678

SWID (2011-2012) SWID—Government of India, West-Bengal. http:// www.wbwridd.gov.in/swid/gw_monitoring2.html. Accessed 12 June 2021

Taylor RG, Scanlon B, Döll P, Rodell M, Van Beek R, Wada Y, Treidel H (2013) Ground water and climate change. Nat Clim Chang 3(4):322-329. https://doi.org/10.1038/nclimate1744

Tehrany MS, Pradhan B, Jebur MN (2013) Spatial prediction of flood susceptible areas using rule based decision tree (DT) and a novel ensemble bivariate and multivariate statistical models in GIS. J Hydrol 504:69-79. https://doi.org/10.1016/j.jhydrol.2013.09.034

Vias JM, Andreo B, Perles MJ, Carrasco F (2005) A comparative study of four schemes for groundwater vulnerability mapping in a diffuse flow carbonate aquifer under Mediterranean climatic conditions. Environ Geol 47(4):586-595. https://doi.org/10.1007/ s00254-004-1185-y
Wang XJ, Zhang JY, Shahid S, ElMahdi A, He RM, Wang XG, Ali M (2012) Gini coefficient to assess equity in domestic water supply in the Yellow River. Mitig Adapt Strat Glob Change 17(1):65-75

Yeh HF, Lee CH, Hsu KC, Chang PH (2008) GIS for the assessment of the groundwater recharge potential zone. Environ Geol 58(1):185195. https://doi.org/10.1007/s00254-008-1504-9

Yohannes DF, Ritsema CJ, Solomon H, Froebrich J, Van Dam JC (2017) Irrigation water management: farmers' practices, perceptions and adaptations at Gumselassa irrigation scheme, North Ethiopia. Agric Water Manag 191:16-28. https://doi.org/10. 1016/j.agwat.2017.05.009

Yong AG, Pearce S (2013) A beginner's guide to factor analysis: focusing on exploratory factor analysis. Tutor Quantitative Method Psychol 9(2):79-94. https://doi.org/10.20982/tqmp.09.2.p079

Publisher's Note Springer Nature remains neutral with regard to jurisdictional claims in published maps and institutional affiliations. 